Article

\title{
Geographical Detection of Urban Thermal Environment Based on the Local Climate Zones: A Case Study in Wuhan, China
}

\author{
Renfeng Wang ${ }^{1}$, Mengmeng Wang ${ }^{1,2, *}$, Zhengjia Zhang ${ }^{1,2}$, Tian $\mathrm{Hu}^{3}$, Jiawen Xing ${ }^{1}$, Zhanjun $\mathrm{He}^{1,2}$ \\ and Xiuguo Liu ${ }^{1}$ (D)
}

1 School of Geography and Information Engineering, China University of Geosciences (Wuhan), Wuhan 430074, China; rf_wang@cug.edu.cn (R.W.); zhangzj@cug.edu.cn (Z.Z.); xingjiawen@cug.edu.cn (J.X.); hezj@cug.edu.cn (Z.H.); liuxiuguo@cug.edu.cn (X.L.)

2 Artificial Intelligence School, Wuchang University of Technology, Wuhan 430223, China

3 Remote Sensing \& Natural Resources Modeling, Department ERIN, LIST, Belvaux, 2450 Luxembourg, Luxembourg; tian.hu@list.lu

* Correspondence: wangmm@cug.edu.cn

check for updates

Citation: Wang, R.; Wang, M.; Zhang, Z.; Hu, T.; Xing, J.; He, Z.; Liu, X. Geographical Detection of Urban Thermal Environment Based on the Local Climate Zones: A Case Study in Wuhan, China. Remote Sens. 2022 14, 1067. https://doi.org/10.3390/ rs14051067

Academic Editors: Yuji Murayama and Christiane Weber

Received: 1 December 2021 Accepted: 15 February 2022 Published: 22 February 2022

Publisher's Note: MDPI stays neutral with regard to jurisdictional claims in published maps and institutional affiliations.

Copyright: () 2022 by the authors Licensee MDPI, Basel, Switzerland. This article is an open access article distributed under the terms and conditions of the Creative Commons Attribution (CC BY) license (https:// creativecommons.org/licenses/by/ $4.0 /)$.

\begin{abstract}
The urban morphology has impacts on the urban thermal environment, which has drawn extensive attention1520]This study explored the relationship between the urban morphology and spatial variation of land surface temperature (LST) in Wuhan by using the local climate zone (LCZ) and seven natural and social factors. A deep learning model (light LCZ model) was used to generate LCZ map in Wuhan, and a geographic detector model was utilized to explore the driving mechanism of LST spatial differentiation. The results show that the LST difference between LCZ classes in summer is greater than that in winter, and the LST of the built-up classes (LCZ 1-10) are significantly higher than that of the vegetation classes in summer. Among the six residential building classes (i.e., LCZ 1-6), LCZ 1 is characterized by compact and high buildings and has the largest average LST. Building density and height have a warming effect, and the building density has a stronger effect than the height. Compared with other natural and social factors, LCZ has the largest explanatory power for LST spatial differentiation in the main urban area and surrounding areas of Wuhan, with explanatory power $(q)$ values reaching 0.660 (summer) and 0.316 (winter). The types of interaction for all pairwise cases are mutual and nonlinear. The strongest interaction is MNDWI-NDBI combination (0.780) in summer and LCZ-NDBI combination (0.460) in winter.
\end{abstract}

Keywords: local climate zone; geodetector; thermal environment

\section{Introduction}

Although the urban area only accounts for $3 \%$ of the global land area, approximately $54 \%$ of the world's population lives in cities [1,2]. With the acceleration of urbanization, an increasing number of people are pouring into cities [3], which has brought a series of environmental and climate problems [4]. The intensity of the urban heat island (UHI) effect is growing due to the increase in impervious surface area, building density and height, and artificial heat emissions in urban areas [5]. The deteriorating urban thermal environment has brought extreme weather events, such as heatwaves, which cause great harm to the health of urban residents [6,7]. By 2080, the annual death toll from the deterioration of the thermal environment will reach 51,795 worldwide [8]. Since the reform and opening up, China's rapid urbanization has brought a series of problems between people, city, nature, and ecological environment. Therefore, understanding the complex processes found at the intersection of urbanization, thermal environment, and human health is important [9], especially in Chinese cities.

The intensity of the UHI effect is an important index for urban thermal environment assessment. The intensities of the UHI and surface UHI (SUHI) are defined by air temperature and land surface temperature (LST) differences between urban and rural areas [10,11]. 
However, the urban thermal environment assessment based on the intensity of UHI and SUHI cannot detect the intensity variation at a finer spatial scale inside the city. An innovative land surface classification system called the local climate zone (LCZ) was proposed on the basis of the city's surface coverage, local thermal state, and physical structure [12]. This system was used to better study the urban thermal environment. LCZ is the result of multiple underlying surface characteristics and their interactions, which has a potential influence on the spatial distribution of LST. The classification system contains 17 categories, including 10 built-up areas, and 7 natural categories [13]. Each category has unique thermal characteristics, which can well characterize the thermal environment of the city [14]. The specific definition standards and displays of LCZs are shown in Table A1 (Appendix A). Using the temperature differences among LCZ classes rather than the traditional urban-rural difference can better explore the UHI differentiation pattern within the city [15]. For urban microclimate and thermal environment research, the LCZ system provides an important mean to analyze the spatiotemporal characteristics of UHI.

At present, some progress has been made in the study of LCZ classification [16]. The LCZ mapping through field surveys is time consuming, laborious, and cannot be extended to city scale. A community-based project called the World Urban Database and Portal Tool (WUDAPT) is committed to creating LCZ maps for global cities and to solve this dilemma $[17,18]$. Since deep learning can well compensate for the shortcomings of traditional machine learning algorithms of shallow levels and weak feature extraction capabilities [19]. Some scholars used deep learning and other techniques to perform LCZ mapping tasks, further improving the quality of LCZ maps [20-22]. On the basis of LCZ mapping, the LST variation among each LCZ class and the related SUHI phenomenon have been investigated in Taipei in Taiwan, China [23], Brno and Prague in Czech [24], Sydney in Australia [25], Texas in the United States of America [26], Dijon in France [27], and Harare in Zimbabwe [28]. The UHI effect analysis based on LCZs shows a promising prospect in the study of urban thermal environment assessment [29-31]. However, quantifying the impact of various climatic ecological factors, especially LCZ, on the spatial differentiation of LST remains insufficient and needs to be further explored.

Exploring the driving mechanism of LST spatial differentiation at the urban scale can help us better alleviate the UHI effect and build an ecologically livable and sustainable city. Most of the current studies explored the influencing factors of the geographical phenomenon by using linear analysis and correlation analysis [32-34]. These methods assumed that a significant linear relationship is found between the driving factor and the spatiotemporal variability of the geographical phenomenon in the entire spatial distribution or time series [35]. However, the spatial distribution and time series of LST do not have a strict standard linear relationship in the complex response process of urban climate and social environment. The geodetector model is based on spatial hierarchical heterogeneity without linear assumption; thus, its results will not be affected by collinearities of multiple variables [36]. The geodetector model has been applied in urban landscape [37], climate ecology [38], public health [39,40], and other fields [41,42].

As the largest city in central China and a well-known stove city in the country, Wuhan suffers huge thermal environment management pressure. This study considers Wuhan as a typical research area and investigates the driving interaction mechanism of LST spatial differentiation in Wuhan on the basis of LCZ and seven natural and social factors by using the geodetector model in summer and winter. The LCZ map in Wuhan was generated by using a deep learning model called Light-LCZ-Net (LLNet). The LST variation of each LCZ class considering the influence of building height and density was investigated. On the basis of geodetector model, the driving interaction mechanism of LST spatial differentiation with eight natural and social factors, such as the population density (POP) and soil-adjusted vegetation index (SAVI), was explored at a finer scale. The study aims to answer the following questions: (1) How does the LCZ affect LST spatial layout? (2) Does the height or density of the building have a greater impact on the local thermal environment? (3) What are the most important factors affecting the LST spatial layout? 
(4) How do natural and social factors interact to influence LST spatial differentiation? The answers are expected to provide data references and suggestions for decision makers of the urban thermal environment, microclimate, and regional planning so as to better create a more livable environment and protect the health of urban residents.

\section{Research Methods}

\subsection{Remote Sensing Image Classification Based on Deep Learning}

The WUDAPT methodology is currently the mainstream approach for LCZ mapping. It requires users to collect samples of each LCZ by themselves, limiting its practicability and making the workflow extremely time consuming [43]. In this study, following the official WUDAPT workflow, based on deep learning technology, sentinel-2 multispectral data and open-source training data set (i.e., So2Sat LCZ42 data set) [44], a LLNet classification model was constructed and used for LCZ mapping in Wuhan. For accuracy evaluation, the validation samples were extracted from Google Earth, and the kappa coefficient, overall accuracy (OA), user's accuracy, and producer's accuracy were calculated on the basis of a confusion matrix.

The deep-learning-based classification model (i.e., LLNet) used in this study mainly includes three components: residual learning structure [45], convolution block attention module (CBAM) [46], and depthwise separable convolution [47], which contribute to integrate features of different levels, optimize features by maximizing the use of high-level semantic information, and make the model lightweight. The classification workflow and structure of the model are illustrated in Figure 1.

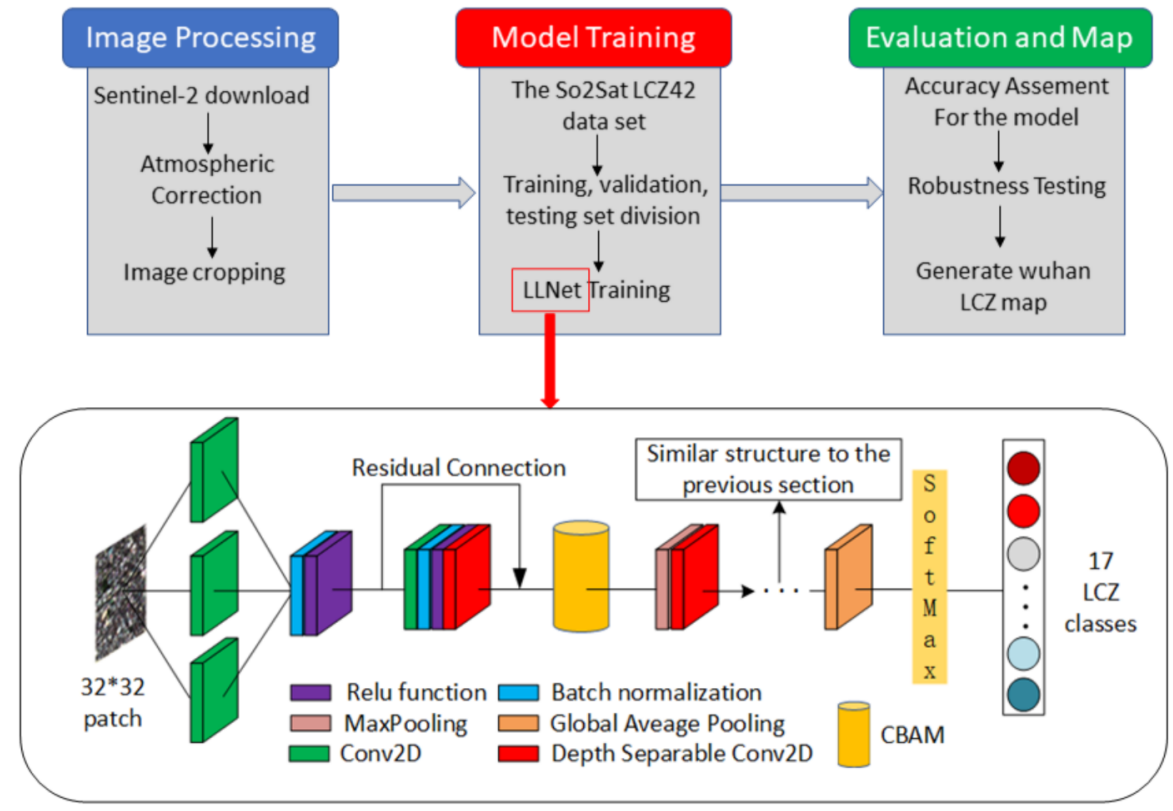

Figure 1. Classification workflow and structure of LLNet.

\subsection{Geodetector Model}

Spatial differentiation is one of the basic features of geographical phenomena. The geodetector is a new spatial statistical method used to detect spatial differentiation and reveal driving factors based on factors, ecology, and an interaction detector. The geodetector model emphasizes the hierarchical heterogeneity of spatial attributes. The study area is divided into several subregions. The basic idea of the geodetector is as follows: if the sum of the variances of the subregions is less than the total variances of the regions, then spatial differentiation is found; if the spatial distribution characteristics of the two variables are consistent, then a strong statistical and spatial correlation is found between the two variables in accordance with the first law of geography [48]. Geodetector $q$ statistic is used to measure the spatial differentiation of the geographical phenomenon and detect the 
interaction relationships between explanatory factors and analytical variables. It has been applied in many fields of natural and social sciences. In this study, the factor detector and interaction detector are used in the driving force analysis of LST.

The factor detector can identify the spatial correlation of LST with corresponding factor data. If no similar spatial heterogeneity is found between the independent variables (potential driving factors) and the dependent variable (LST) in the study area, the $q$ value is low. Factor detectors were used to detect the explanatory degree and importance of each influence factor to LST spatial differentiation. The explanatory degree of each factor is calculated as follows:

$$
\begin{gathered}
q=1-\frac{\sum_{h=1}^{L} N_{h} \sigma_{h}^{2}}{N \sigma^{2}}=1-\frac{S S W}{S S T}, \\
S S W=\sum_{h=1}^{L} N_{h} \sigma_{h}^{2}, \\
S S T=N \sigma^{2},
\end{gathered}
$$

where $q$ is the explanatory power of each influence factor to the spatial differentiation of LST; $h=1,2 \ldots, L ; L$ is the partition of dependent variable $Y$ or impact factor $X ; N_{h}$ and $N$ are the number of units in layer $h$ and region, respectively; $\sigma_{h}^{2}$ and $\sigma^{2}$ are the variances of the $Y$ values of layer $h$ and region, respectively; and SSW and SST are the sum of intralayer variance and total region variance, respectively.

The interaction detector is used to identify the interaction between various influencing factors. The explanatory power of the joint or independent interaction of various potential influencing factors on the spatial differentiation of LST was evaluated with the interaction detector. The evaluation method first calculated the $q$ values for two impact factors $X 1$ and $X 2: q(X 1)$ and $q(X 2)$, and the $q$ value $q(X 1 \cap X 2)$ during their interaction was calculated. $q(X 1), q(X 2)$, and $q(X 1 \cap X 2)$ were compared to evaluate the interaction effect of each factor on the dependent variable. The types of interaction between two covariates are as follows:

Nonlinear weakening :

$$
q(X 1 \cap X 2)<\text { Min. }
$$

Single factor nonlinear weakening: $\operatorname{Min}(q(X 1), q(X 2))<q(X 1 \cap X 2)<\operatorname{Max}(q(X 1), q(X 2)$.

Two - factor enhancement :

$$
q(X 1 \cap X 2)>\operatorname{Max}(q(X 1), q(X 2) .
$$

Independent :

$$
\begin{aligned}
& q(X 1 \cap X 2)=q(X 1)+q(X 2) . \\
& q(X 1 \cap X 2)>q(X 1)+q(X 2) .
\end{aligned}
$$

\section{Study Area and Data}

\subsection{Study Area}

As the most important city in central China, Wuhan is located at $113^{\circ} 41^{\prime} \mathrm{E}-115^{\circ} 05^{\prime} \mathrm{E}$, $29^{\circ} 58^{\prime} \mathrm{N}-31^{\circ} 22^{\prime} \mathrm{N}$, with 13 districts under its jurisdiction. The main urban area of Wuhan consists of six districts: Hankou, Hanyang, Wuchang, Jiangan, Qingshan, and Qiaokou. The six districts have entered a stage of highly urbanized development and are facing problems, such as excessive POP and the deterioration of the urban thermal environment. Wuhan has different urban layouts, building types, and microclimates. From the local scale, the climatic ecological characteristics of Wuhan are complex and diverse, leading to a severe UHI effect, which brings a serious threat to the urban thermal environment and citizens' health, especially in the main urban area of Wuhan. Therefore, we selected the main urban area of Wuhan, namely, the six districts mentioned above, to conduct the experiment of geographic detector and to explore the driving interaction mechanism of LST spatial differentiation in urban core areas on a more detailed scale (Figure 2). 


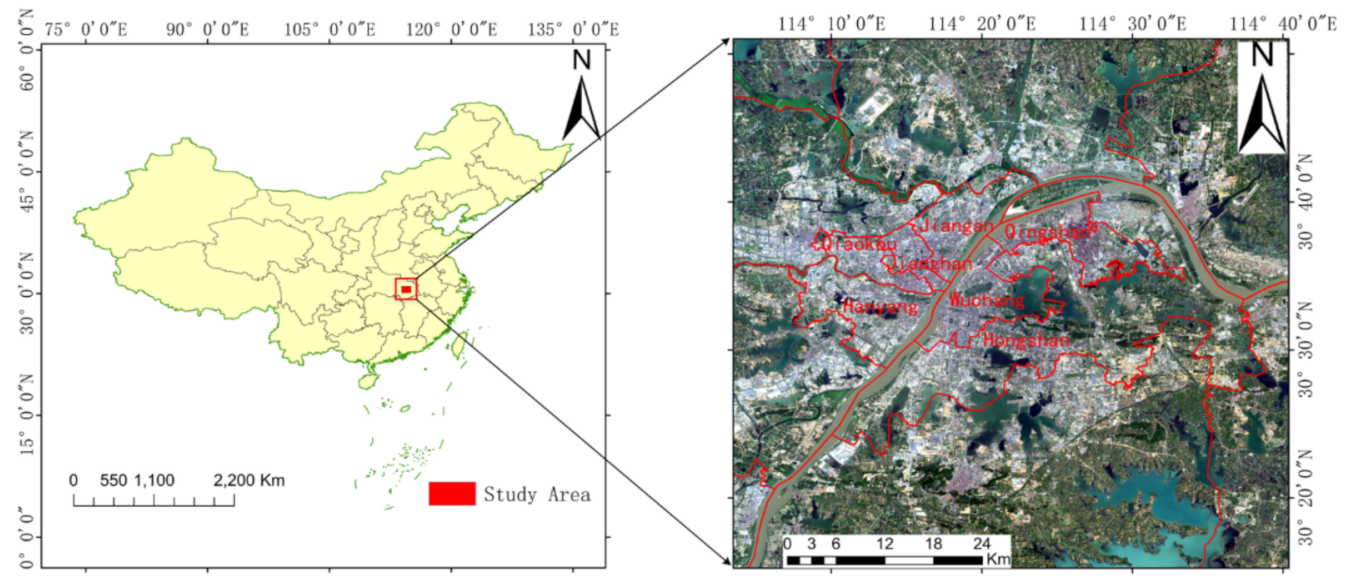

Figure 2. Location of the main urban area and surrounding areas of Wuhan, China (left); Sentinel-2 image (red-green-blue composite) and the boundary of the six districts in the main urban area of Wuhan (right).

\subsection{Multisource Driving Factor Data}

The spatial differentiation of the LST is affected by multiple natural and social factors, and its driving mechanism is complex. Table A2 (Appendix B) summarizes the application of geographic detectors in public health, land cover, ecological environment, and their research areas, dependent variable $\mathrm{Y}$ and independent variable $\mathrm{X}$. On the basis of the existing data and research status, eight potential driving factors were selected to analyze the spatial differential driving and interaction mechanisms of LST in the study area by using the geographical detector. The research on the thermal environment on the city scale requires thermal observation data with high spatial resolution. Landsat- 8 TIRS is a thermal infrared sensor with a high spatial resolution of $100 \mathrm{~m}$, and the TIRS data are freely available to the public. Comprehensively considering the cloud cover of the image and the climate characteristics of Wuhan, two clear-sky Landsat 8 images acquired on 3 August and 25 December 2020 were collected and employed to represent the urban thermal environment of Wuhan in summer (i.e., June, July, and August) and winter (i.e., December, January, and February), respectively. The specific information of data used in this study is shown in Table 1.

The normalized difference vegetation index (NDVI) [49], normalized difference building index (NDBI) [50], and modified normalized difference water index (MNDWI) [51] are important indicators for the identification and characterization of vegetation coverage, urban built-up areas, and water bodies. The soil-adjusted vegetation index (SAVI) can better characterize the vegetation distribution in the main urban area because it has a stronger vegetation identification ability than NDVI in areas with low vegetation coverage [52]. Water with a large specific heat capacity can absorb more heat, whilst vegetation and soil can reduce the temperature and increase the humidity by shielding long- and short-wave radiation and transpiration, respectively. They can alleviate the UHI effect from different angles. At the same time, the specific heat capacity of buildings is small, and high-rise buildings are unconducive to air circulation, which is a potential threat to the urban thermal environment. Therefore, the SAVI, MNDWI, NDBI, and NDVI were selected as four natural impact factors to explore their driving and interaction on LST formation. LST was collected from the Landsat8 Collection 2 Level-2 surface temperature product [53]. NDVI, SAVI, MNDWI, and NDBI were generated by using Landsat-8 OLI multispectral data to perform quantitative inversion. Affected by climate and phenology, the values of NDVI and SAVI change significantly with the change of seasons, while MNDWI and NDBI are less affected by seasons. Therefore, images collected in winter and summer were selected to obtain the values of NDVI and SAVI in the corresponding seasons. The inversion formulas are shown in Table 2. 
Table 1. Data description in this study.

\begin{tabular}{|c|c|c|c|c|}
\hline Data & Date & Satellite Image & Resolution & Sources \\
\hline LCZ & 9 April 2020 & Sentinel-2 & $10 m * 10 m$ & $\begin{array}{l}\text { https: / / scihub.copernicus.eu, } \\
\text { accessed on } 30 \text { November } 2021\end{array}$ \\
\hline LST & 3 August 2020 & Landsat 8 TIRS & $30 m * 30 m$ & $\begin{array}{c}\text { http:/ / www.usgs.gov, accessed on } 30 \\
\text { November } 2021\end{array}$ \\
\hline $\mathrm{LST}^{*}$ & 25 December 2020 & Landsat 8 TIRS & $30 m * 30 m$ & $\begin{array}{c}\text { http:/ / www.usgs.gov, accessed on } 30 \\
\text { November } 2021\end{array}$ \\
\hline NDVI & 3 August 2020 & Landsat 8 OLI & $30 m * 30 m$ & $\begin{array}{c}\text { http:/ / www.usgs.gov, accessed on } 30 \\
\text { November } 2021\end{array}$ \\
\hline NDVI * & 25 December 2020 & Landsat 8 OLI & $30 m * 30 m$ & $\begin{array}{c}\text { http:/ / www.usgs.gov, accessed on } 30 \\
\text { November } 2021\end{array}$ \\
\hline SAVI & 3 August 2020 & Landsat 8 OLI & $30 m * 30 m$ & $\begin{array}{c}\text { http:/ / www.usgs.gov, accessed on } 30 \\
\text { November } 2021\end{array}$ \\
\hline SAVI * & 25 December 2020 & Landsat 8 OLI & $30 m * 30 m$ & $\begin{array}{c}\text { http:/ / www.usgs.gov, accessed on } 30 \\
\text { November } 2021\end{array}$ \\
\hline NDBI & 3 August 2020 & Landsat 8 OLI & $30 m * 30 m$ & $\begin{array}{c}\text { http:/ / www.usgs.gov, accessed on } 30 \\
\text { November } 2021\end{array}$ \\
\hline MNDWI & 3 August 2020 & Landsat 8 OLI & $30 m * 30 m$ & $\begin{array}{c}\text { http:/ / www.usgs.gov, accessed on } 30 \\
\text { November } 2021\end{array}$ \\
\hline NLI & 31 May 2020 & Suomi-NPP-VIIR & $750 \mathrm{~m} * 750 \mathrm{~m}$ & $\begin{array}{l}\text { https:/ / ngdc.noaa.gov, accessed on } \\
30 \text { November } 2021\end{array}$ \\
\hline POP & 2020 & & $100 m * 100 m$ & $\begin{array}{c}\text { http:/ / www.worldpop.org, accessed } \\
\text { on } 30 \text { November } 2021\end{array}$ \\
\hline RD & 2020 & & $100 \mathrm{~m} * 100 \mathrm{~m}$ & $\begin{array}{l}\text { https: / / www.openstreetmap.org, } \\
\text { accessed on } 30 \text { November } 2021\end{array}$ \\
\hline
\end{tabular}

Notes: * represents data in winter. RD and POP are not obtained from satellite images.

The inversion of night light intensity (NLI) from nighttime remote-sensing images can represent the economic and social development degree of a region from the social aspect. Similar to the NLI, the road density (RD) and POP can represent the urban landscape layout in terms of urban traffic and population aggregation. Urban traffic and population distribution are closely related to urban spatial structure, which have an important influence on the spatial differentiation of LST [54]. Therefore, the NLI, RD, and POP were selected as three social influence factors to explore their driving and interaction on the formation of LST. NLI is obtained through the inversion of Suomi-NPP-VIIR night light data collected on 31 May 2020 [55]. The road network data for calculating RD comes from Open Street Map [56]. POP is collected from a high-resolution spatial distribution map of the Chinese population from the World Population website [57]. As an important representation system of the urban local thermal state, LCZ has physical, social, and high-level semantic features of surface partitioning. Its effect on the LST has not been quantitatively investigated. Therefore, LCZ is selected as an important driving factor in the geographic detection of LST. All the data used for geodetector calculations are resampled to a spatial resolution of $100 \mathrm{~m} * 100 \mathrm{~m}$. Figure 3 shows the spatial distribution of potential driving factors and LST in the study area. 
Table 2. Factors used in the geographic detector and their calculation formulas.

\begin{tabular}{cc}
\hline Potential Driving Factors & Formulas \\
\hline LST & {$[54]$} \\
NDVI & NDVI $=\left(\rho_{\text {NIR }}-\rho_{\text {Red }}\right) /\left(\rho_{\text {NIR }}+\rho_{\text {Red }}\right)$ \\
SAVI & SAVI $=(1+L)\left(\rho_{\text {NIR }}-\rho_{\text {Red }}\right) /\left(\rho_{\text {NIR }}+\rho_{\text {Red }}+L\right)$ \\
NDBI & NDBI $=\left(\rho_{\text {SWIR } 1}-\rho_{\text {NIR }}\right) /\left(\rho_{\text {SWIR } 1}+\rho_{\text {NIR }}\right)$ \\
MNDWI & MNDWI $=\left(\rho_{\text {Green }}-\rho_{\text {SWIRI }}\right) /\left(\rho_{\text {Green }}+\rho_{\text {SWIRI }}\right)$ \\
NLI & NLI $=\ln ($ VIIRS \\
POP & {$[58]$} \\
RD & RD $=L_{\text {Road }} /$ Area $_{\text {circle }}$ \\
\hline
\end{tabular}

Notes: Area $_{\text {circle }}$ represents the square area centered over the pixel, with a side length of $3.5 \mathrm{~km}$; $L_{\text {Road }}$ represents the length of the road inside the square, and $L=0.5$.
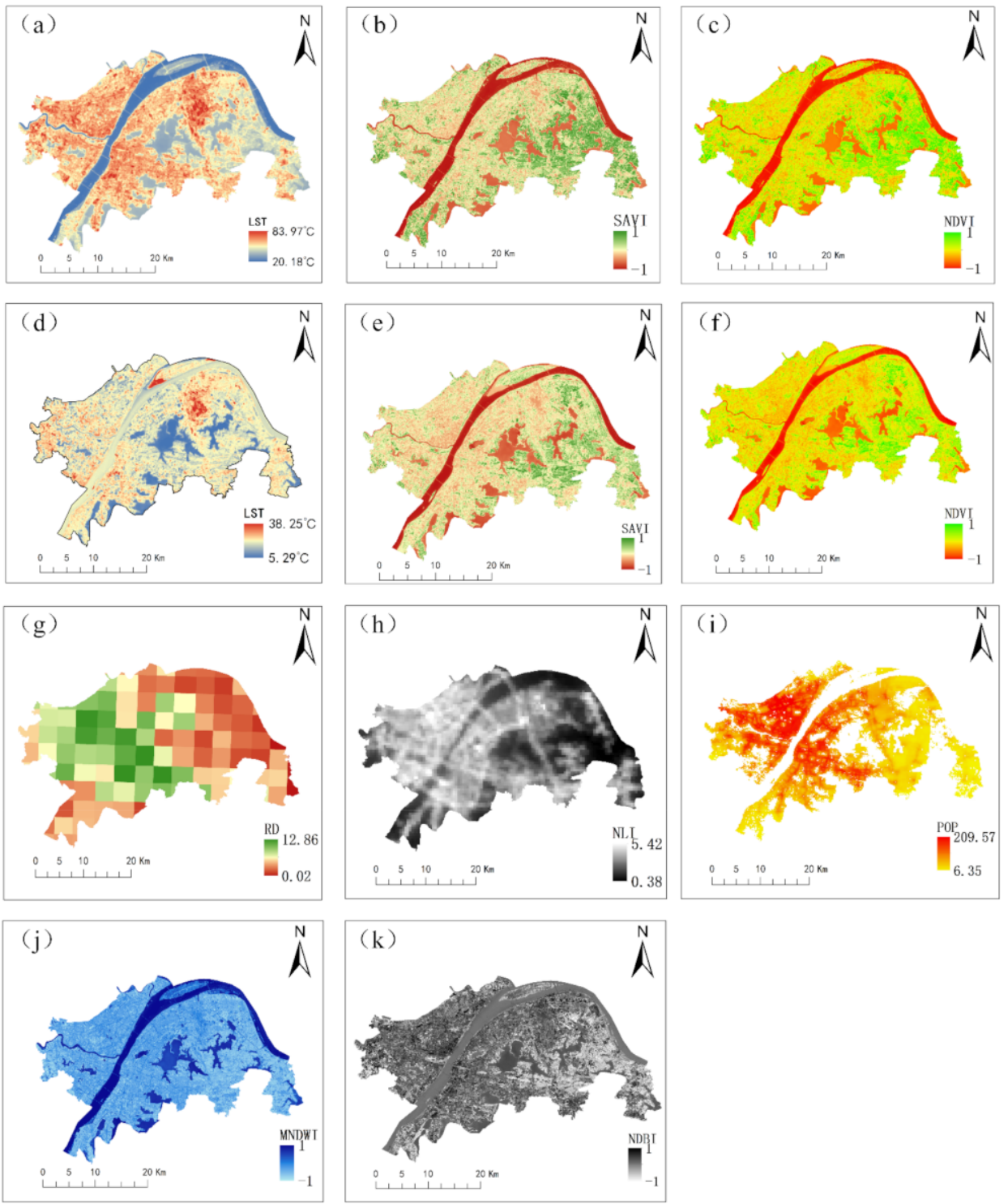

Figure 3. Spatial distribution of LST and potential driving factors in the main urban area of Wuhan. (a) LST in summer; (b) SAVI in summer; (c) NDVI in summer; (d) LST in winter; (e) SAVI in winter; (f) NDVI in winter; (g) road density; (h) nighttime lighting intensity; (i) population density; (j) MNDWI; (k) NDBI. Notes: RD unit: the total length of the road within a radius of $3.5 \mathrm{KM}$ from the pixel point (KM); POP unit: the number of people living in the pixel range. 


\section{Results}

\subsection{Mapping of LCZs}

Figure 4 shows the LCZ classification result of the study area using the LLNet model, and the confusion matrix of the LCZ classification result is shown in Table 3. The OA and kappa coefficient of LCZ classification reach $74.6 \%$ and 0.719 , respectively. Compared with Qiu et al.'s study (2020) [21], the LLNet achieved a similar accuracy, which can meet the research requirements. The accuracy of $L C Z$ natural classes $(A-G)$ is higher than that of the built-up area classes (1-10). The phenomenon of misclassification mainly occurs in built-up area classes (LCZ1-7), some vegetation, and bare land classes (LCZ-B \C). This condition is because the classification standards for built-up areas, vegetation, and bare land are relatively finer, and the spectral curves between the misclassified categories are similar. Overall, the accuracy evaluation showed a good LCZ classification result in Wuhan.
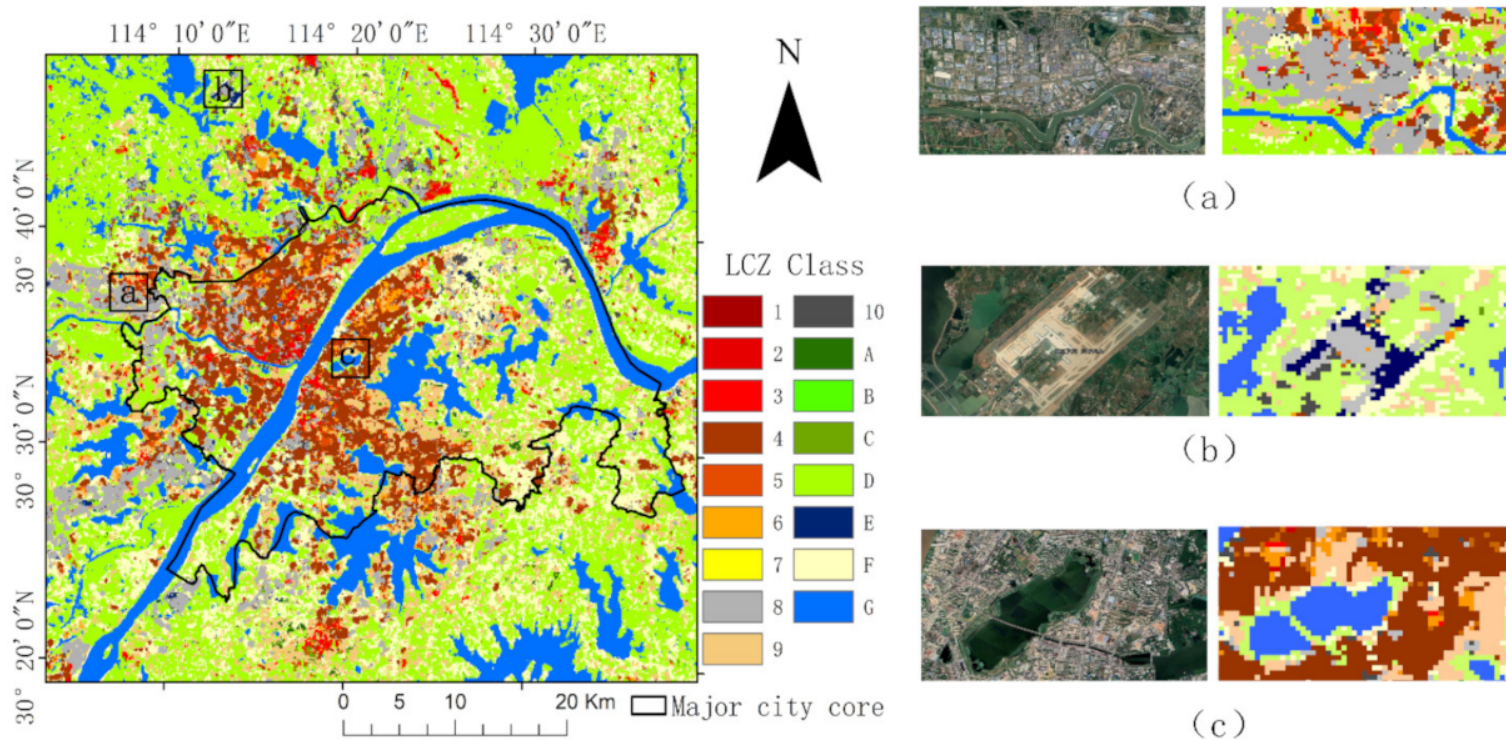

(a)

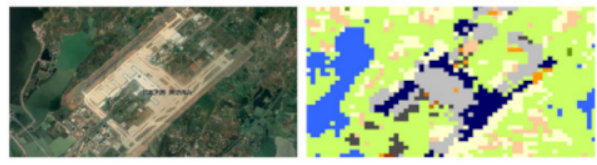

(b)
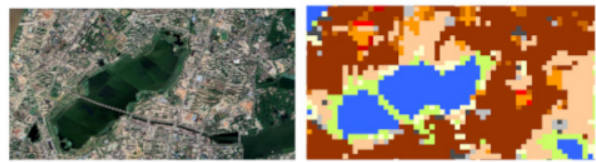

(c)

Figure 4. Classification map of LCZs in the main urban area and surrounding areas from Sentinel-2 image acquired on 9 April 2020. (a) Area containing industrial park; (b) area containing Tianhe International Airport; (c) area containing park, vegetation, and architecture.

In terms of specific land cover, most of the houses in the urban area are classified as LCZ-4, whereas most of the houses in the urban-rural fringe are classified as LCZ-6. LCZ-9 includes some villages scattered around the city and other villages located in the city, which is of great importance for characterizing the spatial distribution of villages around the city. The industrial zones are classified as LCZ-8 and mainly located in the west and southwest of the study area, as shown in Figure 4a. The heavy industrial zone LCZ-10 (such as Wugang industrial zone located in the northeast of East Lake) is confused with bare land LCZ-E and LCZ-F. This condition is because the surface cover of heavy industrial areas and cement-paved bare land have similar spectral features. As shown in Figure $4 b$, a similar phenomenon occurred at Tianhe International Airport in the northwest of Wuhan, which was identified by the model as LCZ-8 and LCZ-E. 
Table 3. Confusion matrix of LCZ classification in the main urban area and surrounding areas.

\begin{tabular}{|c|c|c|c|c|c|c|c|c|c|c|c|c|c|c|c|c|c|c|c|}
\hline LCZ & 1 & 2 & 3 & 4 & 5 & 6 & 7 & 8 & 9 & 10 & A & B & $C$ & D & E & $\mathbf{F}$ & G & $\begin{array}{c}\text { Row } \\
\text { Pixels }\end{array}$ & $\begin{array}{c}\text { User } \\
\text { Acc (\%) }\end{array}$ \\
\hline 1 & 10 & 0 & 0 & 0 & 0 & 0 & 0 & 0 & 0 & 0 & 0 & 0 & 0 & 0 & 0 & 0 & 0 & 10 & 00 \\
\hline 2 & 0 & 64 & 2 & 0 & 4 & 0 & 0 & 0 & 0 & 0 & 0 & 0 & 0 & 0 & 0 & 0 & 0 & 70 & 91 \\
\hline 3 & 1 & 21 & 75 & 2 & 0 & 9 & 1 & 0 & 14 & 0 & 0 & 0 & 0 & 0 & 1 & 1 & 0 & 125 & 60 \\
\hline 4 & 8 & 7 & 3 & 282 & 32 & 8 & 0 & 0 & 0 & 2 & 1 & 0 & 0 & 0 & 2 & 5 & 0 & 350 & 81 \\
\hline 5 & 0 & 22 & 17 & 12 & 117 & 5 & 0 & 0 & 0 & 2 & 0 & 0 & 0 & 0 & 1 & 0 & 0 & 176 & 66 \\
\hline 6 & 1 & 17 & 11 & 3 & 15 & 54 & 0 & 0 & 4 & 0 & 0 & 0 & 0 & 0 & 1 & 0 & 0 & 106 & 51 \\
\hline 7 & 0 & 0 & 0 & 0 & 0 & 0 & 0 & 0 & 0 & 0 & 0 & 0 & 0 & 0 & 0 & 0 & 0 & 0 & 00 \\
\hline 8 & 0 & 0 & 0 & 0 & 1 & 0 & 0 & 52 & 1 & 14 & 0 & 0 & 0 & 0 & 3 & 0 & 0 & 71 & 73 \\
\hline 9 & 0 & 4 & 8 & 5 & 7 & 7 & 0 & 1 & 237 & 3 & 12 & 10 & 4 & 22 & 1 & 5 & 0 & 326 & 73 \\
\hline 10 & 0 & 0 & 0 & 1 & 0 & 0 & 0 & 0 & 3 & 35 & 0 & 0 & 0 & 0 & 0 & 0 & 0 & 39 & 90 \\
\hline A & 0 & 0 & 0 & 0 & 0 & 0 & 0 & 0 & 0 & 0 & 105 & 1 & 5 & 4 & 0 & 0 & 0 & 115 & 91 \\
\hline B & 0 & 0 & 0 & 0 & 0 & 0 & 0 & 0 & 0 & 0 & 1 & 4 & 0 & 0 & 0 & 0 & 0 & 5 & 80 \\
\hline $\mathrm{C}$ & 0 & 1 & 1 & 0 & 0 & 0 & 0 & 0 & 4 & 0 & 3 & 0 & 49 & 2 & 0 & 1 & 0 & 61 & 80 \\
\hline D & 0 & 1 & 3 & 1 & 0 & 2 & 7 & 2 & 36 & 8 & 11 & 6 & 22 & 245 & 7 & 7 & 3 & 361 & 68 \\
\hline $\mathrm{E}$ & 0 & 0 & 0 & 0 & 0 & 0 & 0 & 1 & 0 & 0 & 0 & 0 & 0 & 0 & 44 & 1 & 0 & 46 & 96 \\
\hline $\mathrm{F}$ & 0 & 0 & 0 & 0 & 0 & 1 & 2 & 5 & 17 & 6 & 7 & 7 & 8 & 34 & 13 & 168 & 0 & 268 & 63 \\
\hline G & 0 & 0 & 0 & 0 & 0 & 0 & 0 & 0 & 0 & 0 & 0 & 0 & 0 & 5 & 0 & 0 & 197 & 202 & 98 \\
\hline $\begin{array}{l}\text { Column } \\
\text { pixels }\end{array}$ & 20 & 137 & 120 & 306 & 176 & 86 & 10 & 61 & 316 & 70 & 140 & 28 & 88 & 312 & 73 & 188 & 200 & 2331 & $\begin{array}{c}\text { kappa: } \\
0.7192\end{array}$ \\
\hline $\begin{array}{l}\text { Producer } \\
\text { Acc }(\%)\end{array}$ & 50 & 47 & 63 & 92 & 66 & 63 & 00 & 85 & 75 & 50 & 75 & 14 & 56 & 79 & 60 & 89 & 98 & \multicolumn{2}{|c|}{$\begin{array}{c}\text { OA: } \\
0.7456\end{array}$} \\
\hline
\end{tabular}

The built-up and natural classes are well distinguished in the classification map (c), and the main urban area of the city is dominated by built-up classes (LCZ1-6). More information can be obtained in Table A1 (Appendix A). Different from the circular LCZs' spatial layout of other cities in China, Wuhan is divided into three urban centers (i.e., Hankou, Wuchang, and Hanyang) by the Yangtze River and Han River. LCZ1-5 types are scattered in the three urban centers, where LCZ-4, which mainly covers high-rise residential areas of the city, occupies the largest proportion. Among the natural classes, LCZ-D accounts for the largest proportion, which is mainly composed of farmland distributed around cities and rural areas. As shown in Figure 4, the main urban area of Wuhan presents a tight structure after decades of development and expansion, which has an impact on the thermal environment of the city.

\subsection{Study on Wuhan Urban Thermal Environment Based on LCZs}

In this section, the average LST of each LCZ category is calculated to investigate the relationships between LST and LCZs in Wuhan in summer and winter based on the abovementioned LST and LCZ data. Figures 5 and 6 show that the LST differences between LCZ classes in summer are greater than that in winter. The LST of the built-up classes (LCZ 1-10) is significantly higher than that of the vegetation classes in summer. The exposed surface type (i.e., LCZ-E) has the highest mean LST in summer $\left(52.94{ }^{\circ} \mathrm{C}\right)$ and the second highest mean LST in winter $\left(13.26^{\circ} \mathrm{C}\right)$ due to the high surface albedo of cement, asphalt, and other materials. LCZ-8 has the highest LST among the built-up classes (LCZ1-LCZ10), reaching $52.66{ }^{\circ} \mathrm{C}$ and $13.36{ }^{\circ} \mathrm{C}$ in summer and winter, respectively. This finding is mainly due to the special materials for building rooves in the industrial park, intense heat emission intensity, and industrial electricity consumption [59]. The mean LST of LCZ-10 defined as a heavy industrial zone is $49.63^{\circ} \mathrm{C}$ in summer and $12.48{ }^{\circ} \mathrm{C}$ in winter, lower than the mean LST of LCZ-8. This condition is because misclassification occurs between LCZ-10 and LCZ-E. LCZ-G has the lowest mean LST, which is only $34.85^{\circ} \mathrm{C}$ in summer and $15.03{ }^{\circ} \mathrm{C}$ in winter, respectively. Transpiration of water bodies and vegetation is of great importance to alleviate the UHI effect. As can be observed in Figure 6, the LST of water bodies (LCZ-G) varies obviously in summer and winter. The LST difference between the Yangtze River and inland lakes is significant, indicating that the same LCZ type land parcel also shows different microclimate characteristics due to different urban locations. The thermal environment within a city depends on land use type and other factors, such as the interaction between local and atmospheric circulation. 

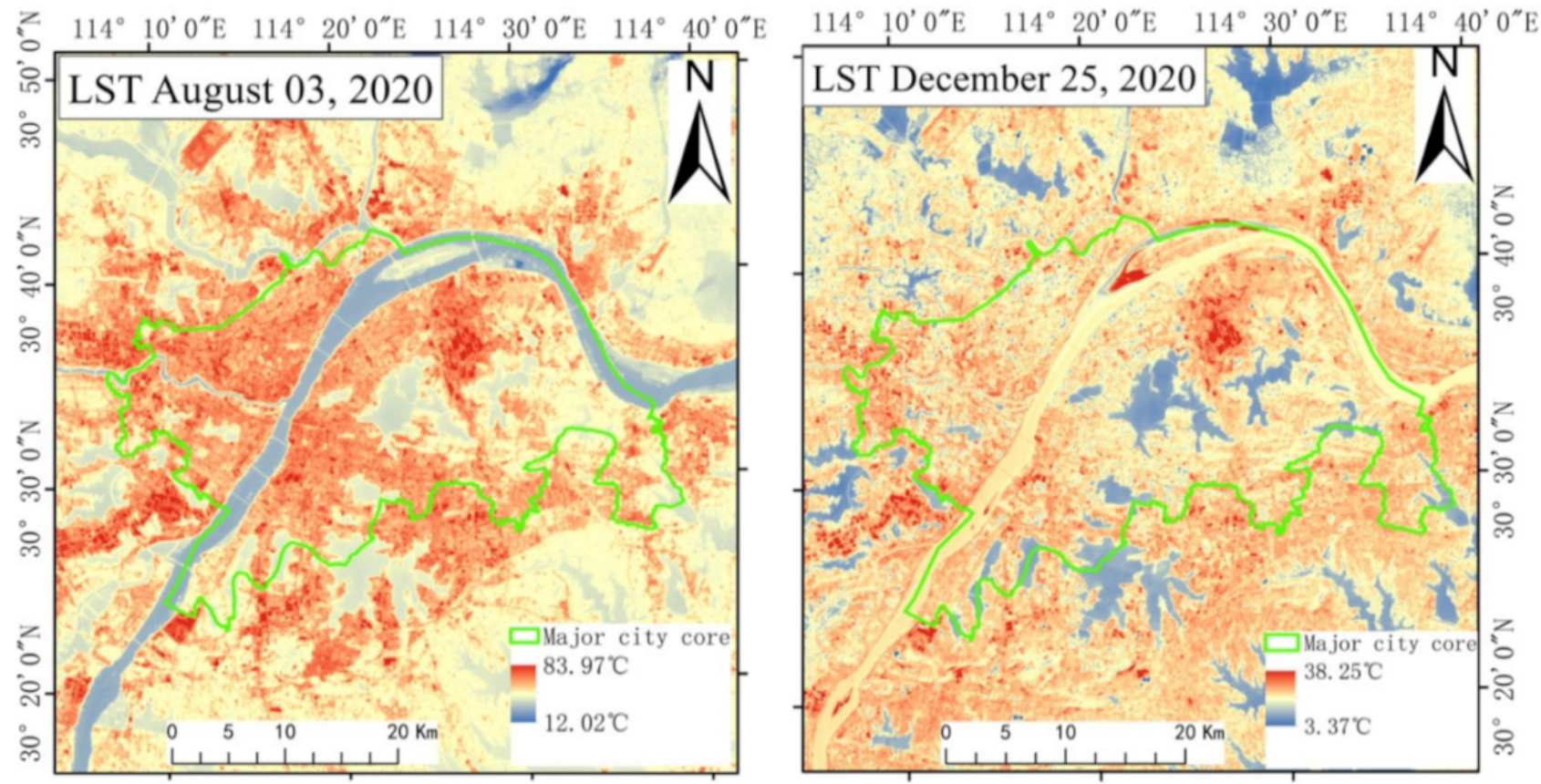

Figure 5. LST in summer (left) and in winter (right) in Wuhan.

We investigated the impacts of building height and density on the thermal environment among six built-up area classes (i.e., LCZ1-LCZ6), in which most of the urban population lives. Table 4 describes the characteristics of building height and density for the six built-up classes (LCZ1-LCZ6). The average LST difference of buildings of the same density but different height and of the same height but different density types are calculated statistically and summarized in Figure 7. Except for the LST differences of LCZ5-LCZ6 and LCZ4-LCZ6 groups in winter being slightly lower than $0{ }^{\circ} \mathrm{C}$, the LST differences in other cases are all higher than $0{ }^{\circ} \mathrm{C}$. This finding indicates that in the case of the same height or the same density, the built-up area with a higher building density or height has a higher average LST. For the compact built-up area, the LST differences of LCZ1-LCZ2 and LCZ2-LCZ3 are $0.55{ }^{\circ} \mathrm{C}$ and $1.01{ }^{\circ} \mathrm{C}$ in summer and $0.21{ }^{\circ} \mathrm{C}$ and $0.10^{\circ} \mathrm{C}$ in winter, respectively. In the open built-up area, the LST differences of LCZ4-LCZ5 and LCZ5-LCZ6 are $0.36{ }^{\circ} \mathrm{C}$ and $0.69{ }^{\circ} \mathrm{C}$ in summer and $0.13{ }^{\circ} \mathrm{C}$ and $-0.23^{\circ} \mathrm{C}$ in winter, respectively. The LST differences for the open built-up area are smaller than that of the compact built-up area because the open built-up area contains more complex features, which can reduce the impact of buildings on LST to a certain extent.

For the high-rise built-up area, the LST difference of LCZ1-LCZ4 reaches $1.93{ }^{\circ} \mathrm{C}$ in summer and $0.87^{\circ} \mathrm{C}$ in winter, respectively. For the middle-rise built-up area, the LST difference of LCZ2-LCZ5 reaches $1.74{ }^{\circ} \mathrm{C}$ in summer and $0.79{ }^{\circ} \mathrm{C}$ in winter, respectively. For the low-rise built-up area, the LST difference of LCZ3-LCZ6 reaches $1.42{ }^{\circ} \mathrm{C}$ in summer and $0.46{ }^{\circ} \mathrm{C}$ in winter, respectively. The LST differences between compact and open builtup areas shows a gradual decrease from high-rise to middle-rise and low-rise. The high building height affects the regional air circulation and surface evapotranspiration, thereby causing heat accumulation and higher LST difference in higher building areas. The average LST difference of LCZ pairs with the same building height type and different building density types (i.e., LCZ1-LCZ4, LCZ2-LCZ5, and LCZ3-LCZ6) is $1.70{ }^{\circ} \mathrm{C}$ in summer and $0.71{ }^{\circ} \mathrm{C}$ in winter, respectively. The average LST difference of LCZ pairs with the same building density type and different building height type (i.e., LCZ1-LCZ2, LCZ2-LCZ3, LCZ4-LCZ5, LCZ5-LCZ6, LCZ1-LCZ3, and LCZ4-LCZ6) is $0.87^{\circ} \mathrm{C}$ in summer and $0.07^{\circ} \mathrm{C}$ in winter, respectively. Therefore, the building density and height have a warming effect on the local thermal environment, and the influence of building density on the urban thermal environment is larger, especially in summer. 


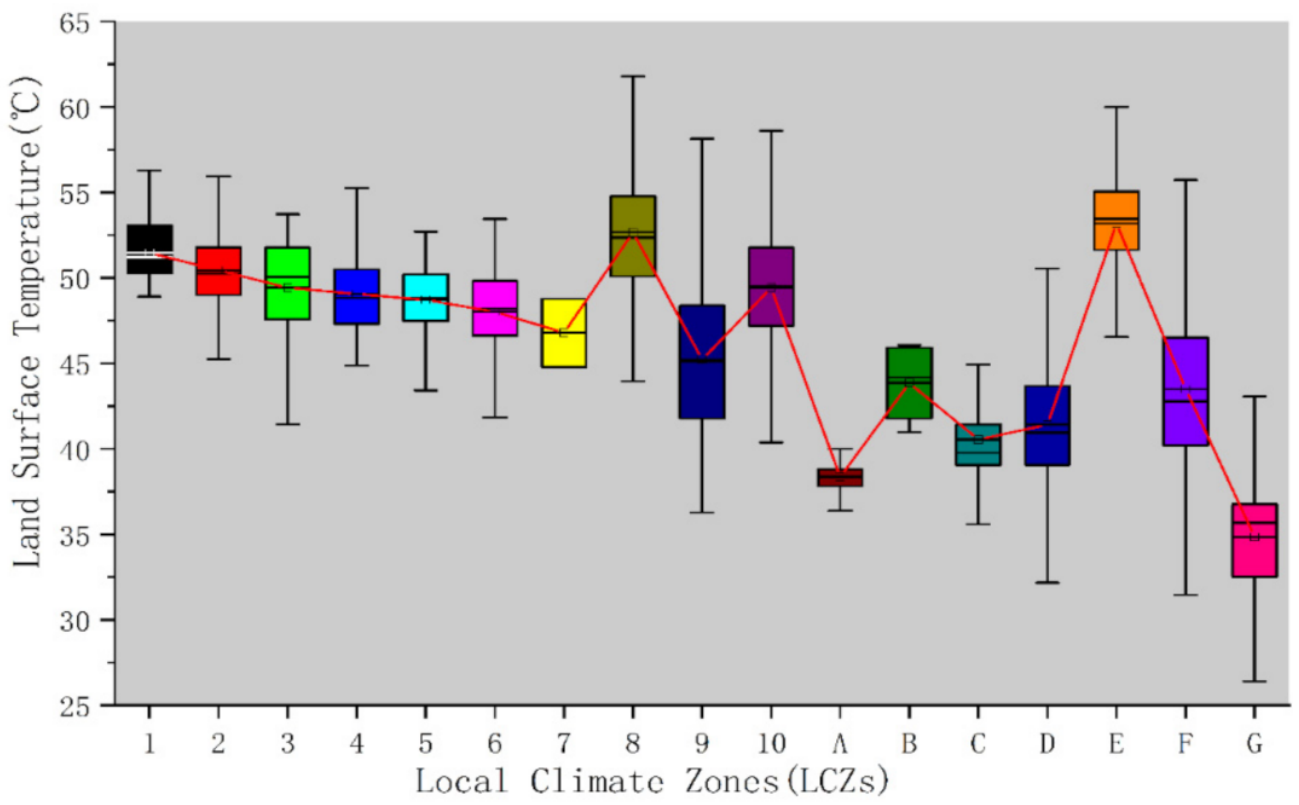

(a) In summer (3 August 2020)

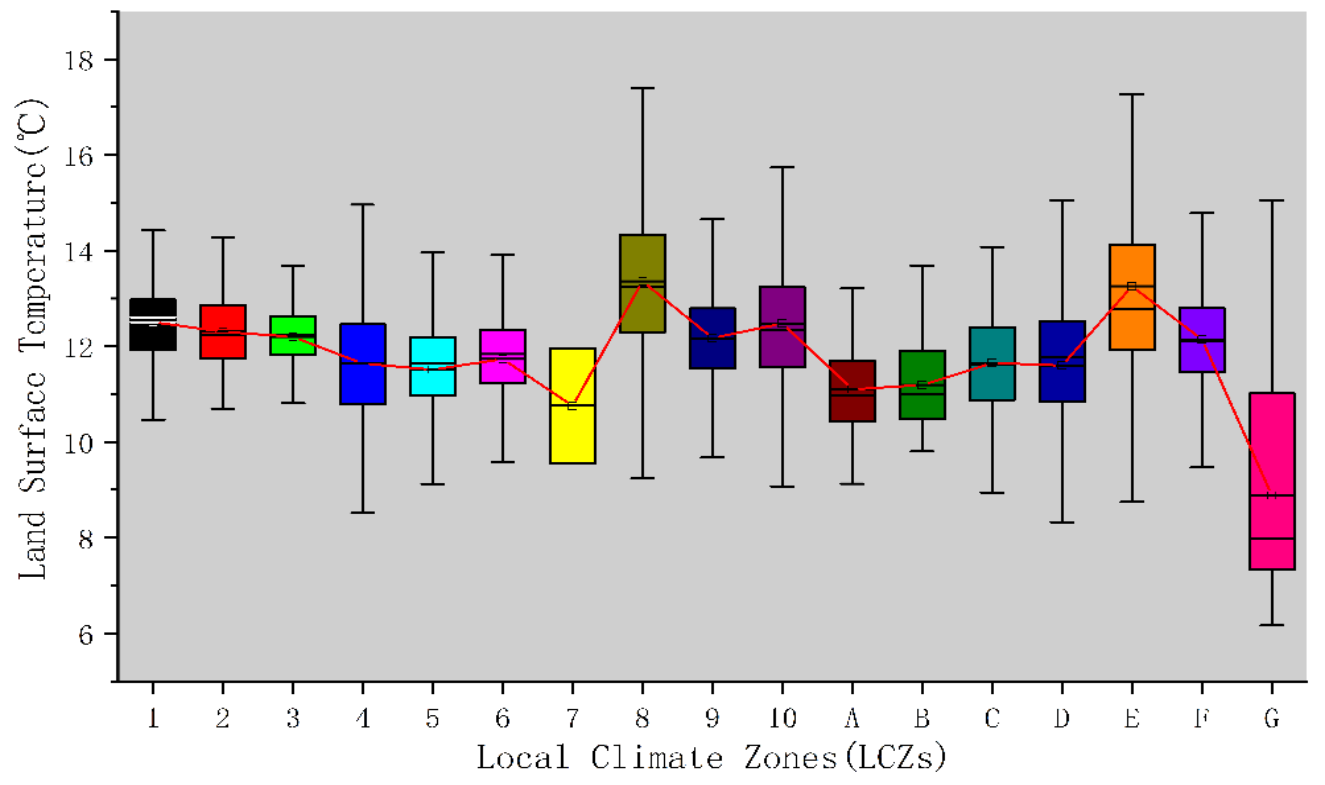

(b) In winter (25 December 2020)

Figure 6. Mean LST of each LCZ class in Wuhan in (a) summer and (b) winter. 
Table 4. Google Earth and Street View photo of built-up LCZ classes (1-6) and typical area.

\begin{tabular}{|c|c|c|c|}
\hline LCZ classes & Google Earth & Street View & Typical Area \\
\hline $\begin{array}{c}\text { LCZ } 1 \\
\text { compact } \\
\text { high-rise }\end{array}$ & & & $\begin{array}{l}\text { Central business district } \\
\text { (CBD) }\end{array}$ \\
\hline $\begin{array}{l}\text { LCZ } 2 \\
\text { compact } \\
\text { mid-rise }\end{array}$ & & & $\begin{array}{l}\text { Old traditional residential } \\
\text { area }\end{array}$ \\
\hline $\begin{array}{l}\text { LCZ } 3 \\
\text { compact } \\
\text { low-rise }\end{array}$ & & & Urban villages \\
\hline $\begin{array}{c}\text { LCZ } 4 \\
\text { open } \\
\text { high-rise }\end{array}$ & & & $\begin{array}{l}\text { CBD or high-rise } \\
\text { residential building }\end{array}$ \\
\hline $\begin{array}{c}\text { LCZ } 5 \\
\text { open } \\
\text { mid-rise }\end{array}$ & & & New residential district \\
\hline $\begin{array}{c}\text { LCZ } 6 \\
\text { open } \\
\text { low-rise }\end{array}$ & & & Upscale villas \\
\hline
\end{tabular}

\subsection{Spatial Differentiation Driving Interaction Mechanism of LST in Wuhan}

The impact of eight natural and social factors on the LST spatial differentiation in the main urban area of Wuhan in summer and winter was explored on the basis of the geographical detector model. Table 5 shows the $q$ values for potential driving factors, and all factors pass the significance test $(p<0.01)$. The impact degree of each impact factor on the spatial differentiation of LST in summer is in the order of LCZ > MNDWI > SAVI $>$ NDVI $>$ POP $>$ NLI $>$ RD $>$ NDBI. The order of influence degree on LST spatial differentiation in winter is $\mathrm{LCZ}>\mathrm{NDVI} / \mathrm{SAVI}>\mathrm{MNDWI}>\mathrm{POP}>\mathrm{NDBI}>\mathrm{NLI}>\mathrm{RD}$. The results show that the driving effect of all factors on LST in summer is significantly higher than that in winter because the spatial differentiation of LST in summer is more obvious. Snow cover and vegetation dormancy may cause low $q$ values of eight factors in winter. 


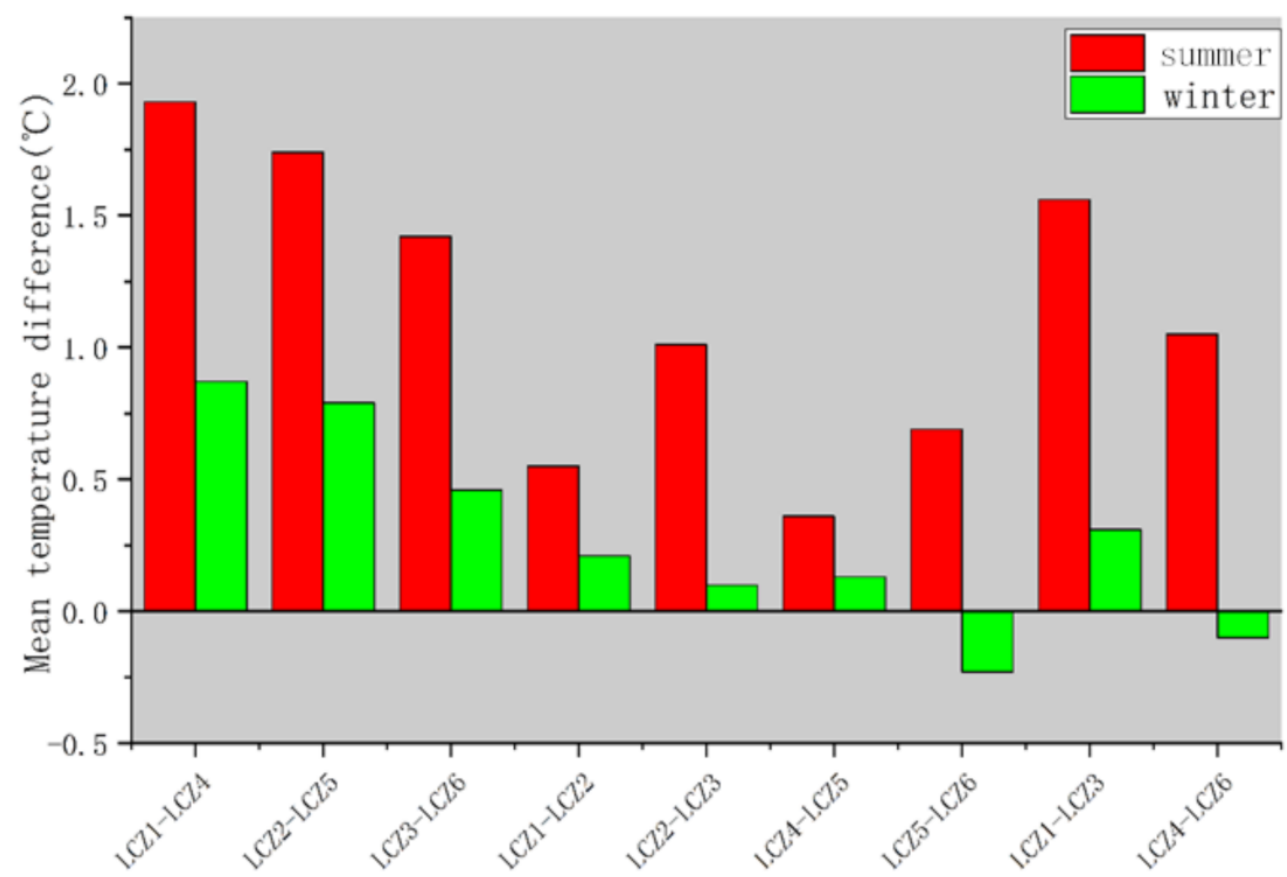

Controlled Experiments

Figure 7. Mean LST differences of built-up LCZ categories in Wuhan.

Table 5. $q$ value calculation results for potential driving factors of LST in Wuhan's major city core in summer and winter.

\begin{tabular}{ccc}
\hline Factors & Summer & Winter \\
\hline LCZ & $\mathbf{0 . 6 5 9 8}$ & $\mathbf{0 . 3 1 5 9}$ \\
NDVI & 0.6044 & 0.2844 \\
SAVI & 0.6269 & 0.2844 \\
NDBI & 0.1446 & 0.0956 \\
MNDWI & 0.6408 & 0.2497 \\
POP & 0.5257 & 0.1866 \\
NLI & 0.3548 & 0.0913 \\
RD & 0.1890 & 0.0206 \\
\hline
\end{tabular}

Notes: The bold font represents the factor with the highest $q$ value of each season.

The LCZ has the largest explanatory power for the spatial differentiation of LST in the study area in summer and winter, and the explanatory power ( $q$ value) reaches 0.660 in summer and 0.316 in winter, respectively. The spatial correlation between LST and LCZ is stronger than that of land cover index (i.e., MNDWI, NDBI, and NDVI) which can only represent a single surface feature. The MNDWI, SAVI, and NDVI mainly represent the intensity of humidity, permeability, and greenness in the city. The $q$ values of the three indexes rank behind the $\mathrm{LCZ}$, whether in summer or winter, showing the important influence of water, soil, and vegetation on urban LST and the thermal environment. In winter, the $q$ value of SAVI and NDVI is the same. In summer, the $q$ value of SAVI is higher than that of NDVI, which is consistent with the conclusion in [52]. NDBI refers to building index and represents the strength of the impervious surface of the main urban area to a certain extent. Its $q$ value ranks last in summer and third from bottom in winter. Compared with SAVI and NDVI, the thermal characteristics of NDBI are relatively stable and are unaffected by seasonal and other environmental factors. In terms of social factors, the $q$ values of NLI, RD, and POP in summer are less than other factors, except NDBI, and are at a low level in winter with $q$ values below 0.2 , indicating that the three social factors have a relatively low impact on LST in the main urban area. The main reason is that the development of the main urban area in Wuhan is close to saturated, resulting in unremarkable spatial 
difference in NLI, POP, and RD. In conclusion, the natural factors show a stronger exploration power than the social factors in the formation of LST in summer.

We studied the interaction relationships between the potential influencing factors and the spatial differentiation of LST in the main urban area of Wuhan based on the interaction detector. Figure 8 shows that the largest $q$ value is MNDWI $\cap$ NDBI (0.78), followed by several pairs with a $0.76 q$ value, for example, MNDWI $\cap$ POP and POP $\cap$ NDVI in summer. In winter, the largest $q$ value is LCZ $\cap$ NDBI (0.46), followed by NDBI $\cap$ NDVI (0.44) and NDBI $\cap$ SAVI (0.44). As shown in Table 5, the single-factor $q$ value of NDBI is extremely low, but its interaction with natural factors (MNDWI, NDVI, SAVI) can reach the highest, whether in summer or winter. One possible reason is that the NDBI and the three factors have mostly achieved coverage of all the surfaces of the main urban area (permeable surface, impervious surface), and the interaction effect between LCZ and other factors is not as apparent as NDBI. This condition is mainly because the surface of each LCZ class is more complex and diverse, and other factors may cause the cancellation of the degree of spatial differentiation during the interaction with the LCZ. Similar to NDBI, the interaction between POP and other natural factors is strong because the spatial distribution of POP and NDBI has a strong correlation. Therefore, how to reasonably configure the spatial pattern of buildings with other natural factors is extremely important. As shown in Figure 8, the interaction between LCZ and each factor is strong, higher than the average level, showing its strong correlation with local human activities, surface coverage, spatial morphology, and other attributes. Heat maps in Figure 8 show that the characteristics of interactions are similar in summer and winter, but the interaction in summer is stronger than in winter. The $q$-values of the interaction between driving factors are not strictly equal to the sum of the $q$-values of the corresponding factors, for example, Max $[q(\mathrm{RD}), q(\mathrm{NLI})]<q(\mathrm{RD} \cap \mathrm{NLI})$ $<q(\mathrm{RD})+q(\mathrm{NLI})$ in summer but $q(\mathrm{NDBI} \cap \mathrm{NLI})>q(\mathrm{NDBI})+q(\mathrm{NLI})$ in winter. This finding indicates that all social and natural factors are dependent of each other, and the influence of multifactor interaction on the spatial differentiation of LST is a double-factor enhancement and nonlinear enhancement relationship rather than a simple linear superposition process.

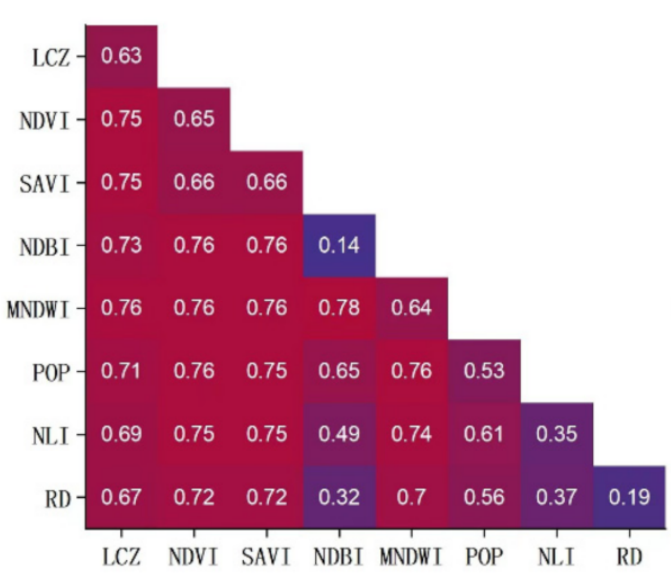

(a)

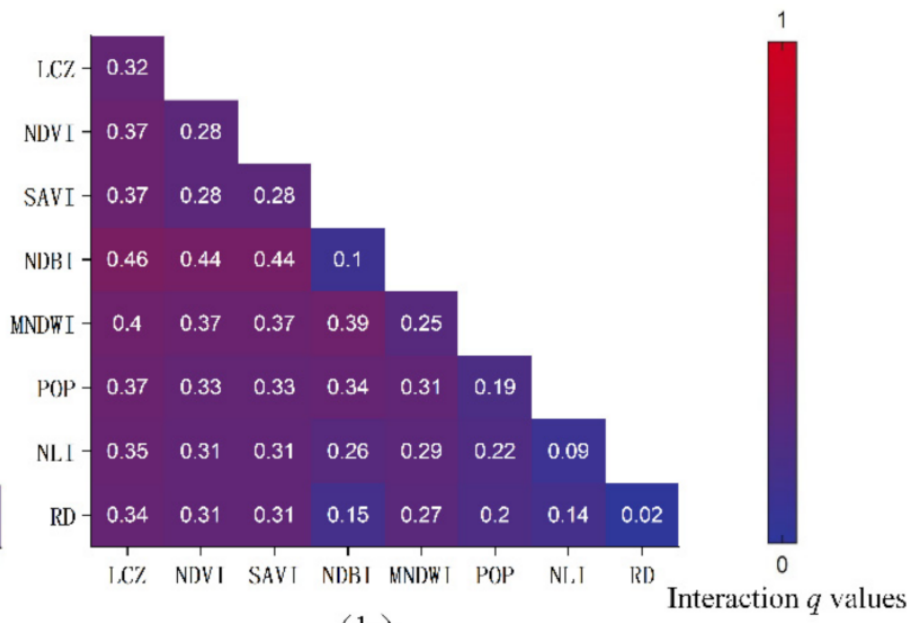

(b)

Figure 8. Average interaction $q$ values among potential driving factors on the spatial differentiation of LST in (a) summer and (b) winter.

\section{Discussion}

\subsection{Accuracy of LCZ Classification}

In this study, a LLNet classification model was constructed and used for LCZ mapping from Sentinel-2 data in Wuhan. As shown in Table 4, some confusions are found between built-up classes and between LCZ-10 (heavy industry), LCZ-E (bare rock or paved), and LCZ-F (bare soil or sand) in Wuhan. LCZ misclassification occurs for many reasons [58]. At the spatial resolution of $10 \mathrm{~m}$, the texture and spatial features of many LCZ classes have no remarkable difference, arousing some confusion and misclassification phenomena in the 
mapping task. The current LCZ system parameter defined by Stewart and Oke shown in Table A3 (Appendix C) is not general for a global scale [60]. One possible reason is that the definition of 17 standard LCZ classes and 11 physical parameters with the associated reference ranges are mainly based on areas in developed countries, which may ignore the rapid urbanization in Asia and Africa [61,62]. The following aspects are considered to further improve the quality of the LCZ system: (i) optimize and adjust the range of parameters (for example, surface albedo and anthropogenic heat output) defined by each LCZ to match the practicality of the LCZ system on a global scale; (ii) define new LCZ class, and the accuracy of LCZ category is affected by the change in climate and the characteristics of building layout. We can consider creating new categories, such as a snow category and mixed building area category, to improve this situation; (iii) expand the application scope. The current application of LCZ is mainly focused on the study of UHI effect, but the research on the morphological effect of various building categories is insufficient. This study initially explored the impact of height and density in the LCZ categories on the urban thermal environment.

\subsection{Uncertainties in Geographical Detection}

This study focused on the geographical detection of LST spatial differentiation in the major city core of Wuhan. We selected eight potential influencing factors as comprehensively as possible. Coupling natural and social multi-source data based on remote-sensing technology for ecological exploration can provide reference for future related research. However, the formation and differentiation mechanism of LST is complicated and affected by many aspects, such as the climate, land cover, and social economy. Selecting driving factor data more scientifically and comprehensively has significance to urban thermal environment assessment based on geographical detection [63]. The uncertainties of LCZs for urban thermal environment investigations are related to the precision of LST. A highprecision inversion algorithm $[64,65]$ is expected to improve LST accuracy. The original resolution of the NLI data $(750 \mathrm{~m})$ is lower than that of LST, which may arouse some uncertainties on the analysis between LST and NLI. In the future, with the advancement of sensor technology, increasing high-precision multisource data can be applied to urban thermal environment assessment based on geographical detection.

The geodetector has a modifiable areal unit problem, including scale and partition effects, where the different spatial statistical grid sizes and different independent variable discretization methods will have an impact on the model results. In accordance with previous research [66], this study resampled all data uniformly to $100 \mathrm{~m}$ and chose the quantile classification as the discretization method, ignoring the regional characteristics of the geographic research. This study explored the relationships between LCZs and LST in summer and winter. The results show that the thermal characteristics of the LCZs in the two seasons are significantly different. Thus, a larger sample of LST collected during nighttime and in different climatic conditions worldwide contributes to a more comprehensive understanding of the relationships between LST and LCZs.

\subsection{Implications for Urban Environment Management}

Stewart et al. (2014) encouraged assessment studies for the urban thermal environment based on LCZs under various climatic conditions. A number of existing studies have proven that the LCZ map plays an irreplaceable role in comprehensively evaluating the UHI effect $[67,68]$. In accordance with Table $5, \mathrm{LCZ}$ is the most prominent factor explaining the spatial differentiation of LST in summer and winter in Wuhan. Recent research in Wuhan, China, indicated that the landscape layout is an important factor in SUHI formation [69]. Therefore, creating a healthy and reasonable LCZ layout can optimize the urban thermal environment to some extent. The mean LST in built-up area classes is higher than that of natural classes, especially in summer. As shown in Figures $6 \mathrm{~b}$ and 7 , the average surface temperature of LCZ6 in winter is higher than that of LCZ4 and LCZ5, which is inconsistent with the general conclusion we have obtained. The shadowing and narrow tube effects of 
urban canyons may be the cause of this phenomenon [62,70]. In winter, the solar radiation is weak, and the wind speed is strong in Wuhan. At this time, in the area of high- and middle-rise buildings, a large airflow is easy to form in the narrow streets to take away heat, resulting in the LST of the open middle- and high-rise areas being lower than the open low-rise areas in winter.

LCZ-A, LCZ-B, and LCZ-G have lower LST due to the evapotranspiration and high specific heat capacity. Therefore, the UHI effect can be greatly alleviated by increasing the area of vegetation and water in built-up areas. As shown in Figure $6 b$, the UHI effect of Wuhan in winter is unremarkable, and the temperature difference within each LCZ category is small. The average LST of LCZ8 and LCZ10 is relatively high in summer and winter. Necessary measures, such as adopting new building materials and adding green space planning [71], should be adopted to improve this situation in future industrial zone construction planning. As shown in Figure 5, the LST of the Yangtze River basin is lower than that of inland lakes in summer, whereas the LST in the Yangtze River basin is higher than those in inland lakes in winter. The differences in flow velocity and water area between the Yangtze River and inland lakes may contribute to this phenomenon [72,73]. Various lakes are found in Wuhan City. In summer, under the influence of subtropical high pressure, the wind speed is low, and the water on the lake surface continues to evaporate. The subtropical high pressure allows steam to remain in the air, forming high-temperature water vapor. However, the LST of the water body in the Yangtze River basin is already extremely low when it flows to Wuhan through the upstream transpiration due to the fast flow rate. In winter, the local circulation has an important effect. The winter monsoon blowing to the city carries a large amount of cold and humid air. Inland lakes with a larger surface area have a greater cooling rate than the narrow Yangtze River. In the future, the impact of water quality differences between the Yangtze River and inland lakes and upstream reservoir on LST should be further explored [74,75].

The population of the Wuhan main city presents a decreasing density distribution from the center to the surrounding area. The huge anthropogenic heat flux in the core area of the city exacerbates the UHI phenomenon. However, directly reducing the population of urban center is impractical due to the scarcity of building resources and features of urban functional areas. To increase the plot ratio, people often choose to increase the density or height of the building. Urban densification and vertical development significantly affect the local thermal environment. In Section 4.2, using the unique building form information provided by the LCZ system, the density of the building has a greater impact on the urban UHI than height. Thus, the building density should be strictly limited in future urban planning and increasing building height appropriately may be considered to alleviate the UHI effect and achieve a balance between the plot ratio and thermal environment.

\section{Conclusions}

In this study, we investigated the thermal characteristics of each LCZ category and the influence of different LCZ categories on the SUHI effect in summer and winter. The spatial differentiation driving interaction mechanism of LST with several potential natural social driving factors data in the major city core of Wuhan was explored by using the geodetector model. The conclusions are as follows: (1) the relationships between the LST and LCZ in summer and winter shows that LCZ map can effectively represent the intensity and spatial distribution of UHI effect, which plays an important role in the evaluation and analysis of urban thermal environment. (2) LCZ ranked the top driving forces for the spatial differentiation of LST at the main urban area of Wuhan in two seasons. The layout of LCZ plays a pivotal role in optimizing the urban thermal environment. (3) The spatial differentiation and driving interaction characteristics of LST in the main urban area of Wuhan are similar in winter and summer, but the driving interaction of various factors in summer is stronger than that in winter. (4) The interactive effect of any two factors on the main urban area of Wuhan shows a relationship of double-factor enhancement and nonlinear enhancement. (5) With other conditions being equal, the building density has a 
greater impact on local thermal environment than building height by using the 3D urban form information (LCZ1-6) provided by the LCZ classification map.

The conclusions and optimization measures of the thermal environment in Wuhan drawn from this study will help Wuhan build a more competitive and sustainable world city with more dynamic urban space, more green and low-carbon ecological environment, and more livable civic communities in the context of drastic global climate change. The results of this study are expected to provide meaningful references and suggestions for the government and other planning agencies to manage urban thermal environment and mitigate the UHI effect at a more refined scale.

Author Contributions: Conceptualization, R.W. and M.W.; methodology, R.W. and M.W.; validation, Z.Z., T.H., J.X., Z.H. and X.L.; writing - original draft preparation, R.W. and M.W.; writing-review and editing, M.W.; funding acquisition, M.W. All authors have read and agreed to the published version of the manuscript.

Funding: This research was funded by the Open Fund of Key Laboratory of National Geographical Census and Monitoring, Ministry of Natural Resources, grant number 2022NGCM06, the National Natural Science Foundation of China, grant numbers 61801443 and 41801348, and the Strategic Priority Research Program of the Chinese Academy of Sciences, grant number XDA19090300.

Data Availability Statement: The data presented in this study are available on request from the corresponding author.

Acknowledgments: We would like to thank the United States Geological Survey (https:/ / glovis.usgs. gov /, accessed on 30 November 2021), Open Street Map (https: / /www.openstreetmap.org/, accessed on 30 November 2021), and World Population website (http:/ / www.worldpop.org/, accessed on 30 November 2021) for providing Sentinel-2, Landsat-8 imagery, and related factors free of charge. Special thanks to Zhu from the German Aerospace Center (DLR) and his team for providing the dataset (So2Sat LCZ42) for deep learning.

Conflicts of Interest: The authors declare no conflict of interest.

\section{Appendix A}

Table A1. Illustration of LCZs and corresponding image display.

\begin{tabular}{|c|c|c|c|}
\hline Built Types & Definition & Land Cover Types & Definition \\
\hline 1. Compact high-rise & $\begin{array}{l}\text { Dense mix of tall buildings to tens of } \\
\text { stories. Few or no trees. Land cover } \\
\text { mostly paved. Concrete, steel, stone, } \\
\text { and glass construction materials. }\end{array}$ & A. Dense trees & $\begin{array}{l}\text { Landscape of wooded deciduous and } \\
\text { evergreen trees. The land cover is } \\
\text { mainly permeable. Representative } \\
\text { areas include natural forests. }\end{array}$ \\
\hline Compact mid-rise & $\begin{array}{l}\text { Dense mix of midrise buildings } \\
\text { (3-9 stories). Few or no trees. Land } \\
\text { cover mostly paved. Stone, brick, tile, } \\
\text { and concrete construction materials. }\end{array}$ & B. Scattered trees & $\begin{array}{l}\text { Lightly wooded landscape of } \\
\text { deciduous and/or evergreen trees. } \\
\text { Land cover mostly pervious (low } \\
\text { plants). Representative areas include } \\
\text { urban park. }\end{array}$ \\
\hline 3. Compact low-rise & $\begin{array}{l}\text { Dense mix of low-rise buildings } \\
\text { (1-3 stories). Few or no trees. Land } \\
\text { cover mostly paved. Stone, brick, tile, } \\
\text { and concrete construction materials. }\end{array}$ & Bush, scrub & $\begin{array}{l}\text { Open arrangement of bushes, shrubs, } \\
\text { and short, woody trees. Land cover } \\
\text { mostly pervious (bare soil or sand). }\end{array}$ \\
\hline
\end{tabular}


Table A1. Cont.

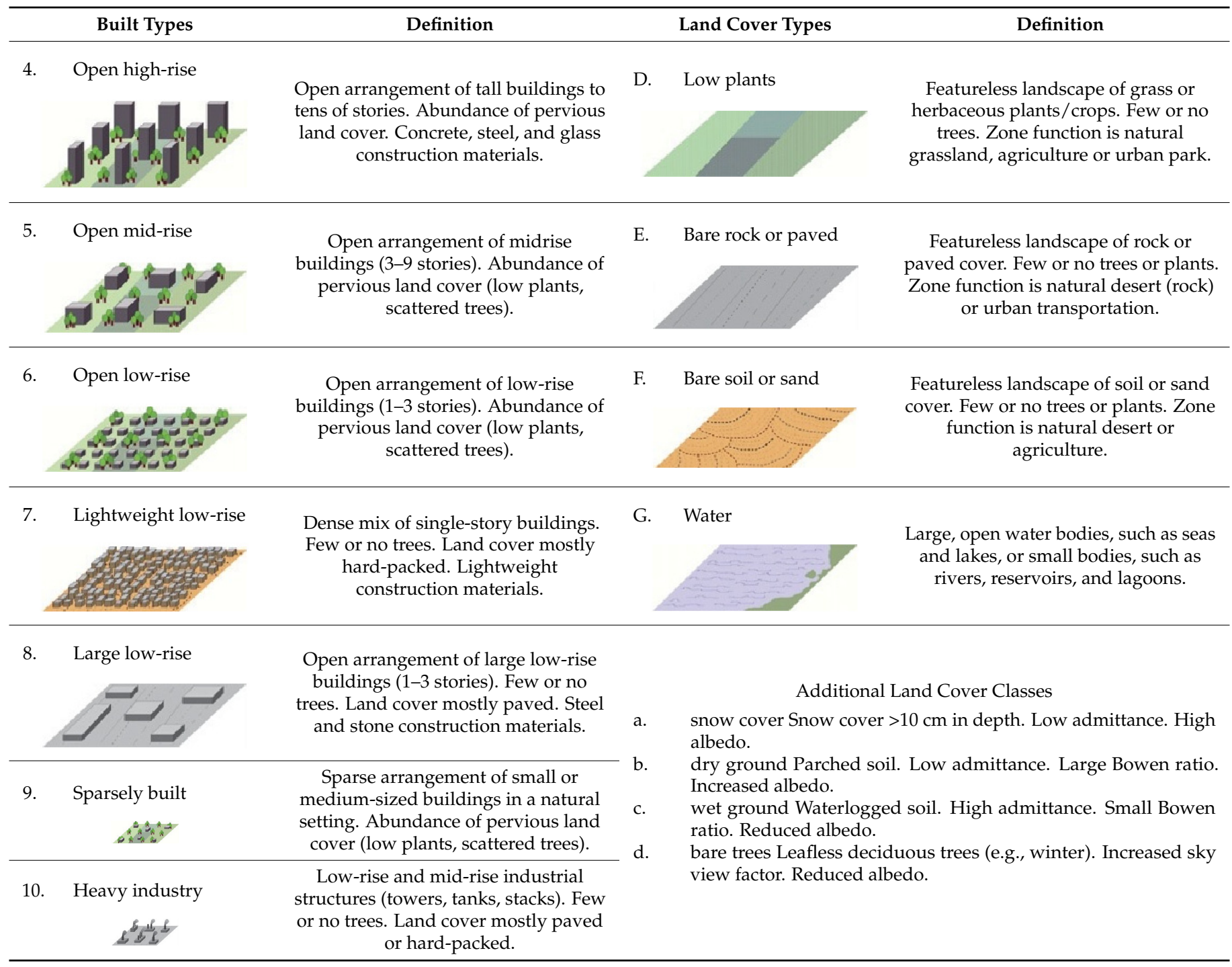




\section{Appendix B}

Table A2. More typical applitications of geodetector.

\begin{tabular}{|c|c|c|c|c|}
\hline Research Question & Study Area & Dependent Variable $Y$ & Independent Variable $X$ & Literature \\
\hline $\begin{array}{l}\text { Factors influencing hand, foot and } \\
\text { mouth disease }\end{array}$ & China & $\begin{array}{l}\text { Hand, foot and mouth } \\
\text { disease incidence }\end{array}$ & $\begin{array}{l}\text { Monthly average temperature, monthly } \\
\text { precipitation, relative humidity, population density, } \\
\text { primary school density, secondary school density, } \\
\text { GDP, industrial structure }\end{array}$ & [76] \\
\hline $\begin{array}{l}\text { Controlling factors of urban } \\
\text { landscape }\end{array}$ & Fujian Xiamen China & Connectivity of forest landscape & Weather, FMPl, elevation, population & [37] \\
\hline $\begin{array}{l}\text { Potential driving factors of } \\
\text { landsurface temperature }\end{array}$ & Tianjin, China & Landsurface temperature & $\begin{array}{c}\text { NDVI, TCG, SAVl, NDBI, MNDWI, TCW, WD, } \\
\text { NLI, RD, RWD }\end{array}$ & [71] \\
\hline $\begin{array}{l}\text { Influence of human activities and } \\
\text { ecological factors on urban surface } \\
\text { temperature }\end{array}$ & Xiamen, China & Urban forest temperature & $\begin{array}{l}\text { Population density, woodland survey, DEM, } \\
\text { remote sensing image, etc }\end{array}$ & [77] \\
\hline $\begin{array}{l}\text { Factor analysis of industral } \mathrm{CO}_{2} \\
\text { emissions }\end{array}$ & Inner Mongolia, China & $\mathrm{CO}_{2}$ emissions & $\begin{array}{l}\text { GDP, industrial structure, urbanization rate, } \\
\text { economic growth rate population and road density }\end{array}$ & [78] \\
\hline $\begin{array}{l}\text { Identification of influe ncing factors } \\
\text { of continental surface cutting degree }\end{array}$ & The United States & Degree of epicontinental cutting & Climate, slope, topography, rock, soil, vegetation & [79] \\
\hline
\end{tabular}




\section{Appendix C}

Table A3. Values of different index properties for LCZ classes.

\begin{tabular}{|c|c|c|c|c|c|c|c|c|c|c|}
\hline LCZ & $\begin{array}{l}\text { Sky View } \\
\text { Factor }\end{array}$ & $\begin{array}{l}\text { Aspect } \\
\text { Ratio }\end{array}$ & $\begin{array}{c}\text { Building } \\
\text { Surface } \\
\text { Fraction }\end{array}$ & $\begin{array}{c}\text { Impervious } \\
\text { Surface } \\
\text { Fraction }\end{array}$ & $\begin{array}{l}\text { Pervious } \\
\text { Surface } \\
\text { Fraction }\end{array}$ & $\begin{array}{l}\text { Height of } \\
\text { Roughness } \\
\text { Elements }\end{array}$ & $\begin{array}{c}\text { Terrain } \\
\text { Roughness } \\
\text { Class }\end{array}$ & $\begin{array}{c}\text { Surface } \\
\text { Admittance }\end{array}$ & $\begin{array}{l}\text { Surface } \\
\text { Albedo }\end{array}$ & $\begin{array}{c}\text { Anthropogenic } \\
\text { Heat Output }\end{array}$ \\
\hline $\begin{array}{c}\text { LCZ } 1 \\
\text { Compact high-rise }\end{array}$ & $0.2-0.4$ & $>2$ & $40-60$ & $40-60$ & $<10$ & $>25$ & 8 & 1500-1800 & $0.10-0.20$ & $50-300$ \\
\hline $\begin{array}{c}\text { LCZ } 2 \\
\text { Compact midrise }\end{array}$ & $0.3-0.6$ & $0.75-2$ & $40-70$ & $30-50$ & $<20$ & $10-25$ & $6-7$ & $1500-2200$ & $0.10-0.20$ & $<75$ \\
\hline $\begin{array}{c}\text { LCZ } 3 \\
\text { Compact low-rise }\end{array}$ & $0.2-0.6$ & $0.75-1.5$ & $40-70$ & $20-50$ & $<30$ & $3-10$ & 6 & 1200-1800 & $0.10-0.20$ & $<75$ \\
\hline $\begin{array}{c}\text { LCZ } 4 \\
\text { Open high-rise }\end{array}$ & $0.5-0.7$ & $0.75-1.25$ & $20-40$ & $30-40$ & $30-40$ & $>25$ & $7-8$ & $1400-1800$ & $0.12-0.25$ & $<50$ \\
\hline $\begin{array}{c}\text { LCZ } 5 \\
\text { Open midrise }\end{array}$ & $0.5-0.8$ & $0.3-0.75$ & $20-40$ & $30-50$ & $20-40$ & $10-25$ & $5-6$ & 1400-2000 & $0.12-0.25$ & $<25$ \\
\hline $\begin{array}{c}\text { LCZ } 6 \\
\text { Open low-rise }\end{array}$ & $0.6-0.9$ & $0.3-0.75$ & $20-40$ & $20-50$ & $30-60$ & $3-10$ & $5-6$ & $1200-1800$ & $0.12-0.25$ & $<25$ \\
\hline $\begin{array}{c}\text { LCZ } 7 \\
\text { Lightweight } \\
\text { low-rise }\end{array}$ & $0.2-0.5$ & $1-2$ & $60-90$ & $<20$ & $<30$ & $2-4$ & $4-5$ & $800-1500$ & $0.15-0.35$ & $<35$ \\
\hline $\begin{array}{c}\text { LCZ } 8 \\
\text { Large low-rise }\end{array}$ & $>0.7$ & $0.1-0.3$ & $30-50$ & $40-50$ & $<20$ & $3-10$ & 5 & 1200-1800 & $0.15-0.25$ & $<50$ \\
\hline $\begin{array}{c}\text { LCZ } 9 \\
\text { Sparsely built }\end{array}$ & $>0.8$ & $0.1-0.25$ & $10-20$ & $<20$ & $60-80$ & $3-10$ & $5-6$ & 1000-1800 & $0.12-0.25$ & $<10$ \\
\hline $\begin{array}{c}\text { LCZ } 10 \\
\text { Heavy industry }\end{array}$ & $0.6-0.9$ & $0.2-0.5$ & $20-30$ & $20-40$ & $40-50$ & 5-15 & $5-6$ & $1000-2500$ & $0.12-0.20$ & $>300$ \\
\hline $\begin{array}{c}\mathrm{LCZ} \text { A } \\
\text { Dense trees }\end{array}$ & $<0.4$ & $>1$ & $<10$ & $<10$ & $>90$ & $3-30$ & 8 & unknown & $0.10-0.20$ & 0 \\
\hline $\begin{array}{c}\text { LCZ B } \\
\text { Scattered trees }\end{array}$ & $0.5-0.8$ & $0.25-0.75$ & $<10$ & $<10$ & $>90$ & $3-15$ & $5-6$ & 1000-1800 & $0.15-0.25$ & 0 \\
\hline
\end{tabular}


Table A3. Cont.

\begin{tabular}{|c|c|c|c|c|c|c|c|c|c|c|}
\hline LCZ & $\begin{array}{l}\text { Sky View } \\
\text { Factor }\end{array}$ & $\begin{array}{l}\text { Aspect } \\
\text { Ratio }\end{array}$ & $\begin{array}{l}\text { Building } \\
\text { Surface } \\
\text { Fraction }\end{array}$ & $\begin{array}{c}\text { Impervious } \\
\text { Surface } \\
\text { Fraction }\end{array}$ & $\begin{array}{c}\text { Pervious } \\
\text { Surface } \\
\text { Fraction }\end{array}$ & $\begin{array}{l}\text { Height of } \\
\text { Roughness } \\
\text { Elements }\end{array}$ & $\begin{array}{c}\text { Terrain } \\
\text { Roughness } \\
\text { Class }\end{array}$ & $\begin{array}{c}\text { Surface } \\
\text { Admittance }\end{array}$ & $\begin{array}{l}\text { Surface } \\
\text { Albedo }\end{array}$ & $\begin{array}{c}\text { Anthropogenic } \\
\text { Heat Output }\end{array}$ \\
\hline $\begin{array}{c}\text { LCZC } \\
\text { Bush, scrub }\end{array}$ & $0.7-0.9$ & $0.25-1.0$ & $<10$ & $<10$ & $>90$ & $<2$ & $4-5$ & $700-1500$ & $0.15-0.30$ & 0 \\
\hline $\begin{array}{c}\text { LCZ D } \\
\text { Low plants }\end{array}$ & $>0.9$ & $<0.1$ & $<10$ & $<10$ & $>90$ & $<1$ & $3-4$ & $1200-1600$ & $0.15-0.25$ & 0 \\
\hline $\begin{array}{c}\text { LCZ E } \\
\text { Bare rock or paved }\end{array}$ & $>0.9$ & $<0.1$ & $<10$ & $>90$ & $<10$ & $<0.25$ & $1-2$ & $1200-2500$ & $0.15-0.30$ & 0 \\
\hline $\begin{array}{c}\text { LCZ F } \\
\text { Bare soil or sand }\end{array}$ & $>0.9$ & $<0.1$ & $<10$ & $<10$ & $>90$ & $<0.25$ & $1-2$ & $600-1400$ & $0.20-0.35$ & 0 \\
\hline $\begin{array}{l}\text { LCZ G } \\
\text { Water }\end{array}$ & $>0.9$ & $<0.1$ & $<10$ & $<10$ & $>90$ & - & 1 & 1500 & $0.02-0.10$ & 0 \\
\hline
\end{tabular}




\section{References}

1. Cohen, B. Urbanization, City growth, and the New United Nations development agenda. Cornerstone 2015, 3, 4-7.

2. Liu, Z.; He, C.; Zhou, Y.; Wu, J. How much of the world's land has been urbanized, really? A hierarchical framework for avoiding confusion. Landsc. Ecol. 2014, 29, 763-771. [CrossRef]

3. Yusuf, Y.A.; Pradhan, B.; Idrees, M.O. Spatio-temporal assessment of urban heat island effects in Kuala Lumpur metropolitan city using landsat images. J. Indian Soc. Remote Sens. 2014, 42, 829-837. [CrossRef]

4. Wang, Y.; Du, H.; Xu, Y.; Lu, D.; Wang, X.; Guo, Z. Temporal and spatial variation relationship and influence factors on surface urban heat island and ozone pollution in the Yangtze River Delta, China. Sci. Total Environ. 2018, 631, 921-933. [CrossRef] [PubMed]

5. Arnfield, A.J. Two decades of urban climate research: A review of turbulence, exchanges of energy and water, and the urban heat island. Int. J. Climatol. J. R. Meteorol. Soc. 2003, 23, 1-26. [CrossRef]

6. Kalisa, E.; Fadlallah, S.; Amani, M.; Nahayo, L.; Habiyaremye, G. Temperature and air pollution relationship during heatwaves in Birmingham, UK. Sustain. Cities Soc. 2018, 43, 111-120. [CrossRef]

7. Mayrhuber, E.A.-S.; Dückers, M.L.; Wallner, P.; Arnberger, A.; Allex, B.; Wiesböck, L.; Wanka, A.; Kolland, F.; Eder, R.; Hutter, H.-P. Vulnerability to heatwaves and implications for public health interventions-A scoping review. Environ. Res. 2018, 166, 42-54. [CrossRef]

8. Guo, Y.; Gasparrini, A.; Li, S.; Sera, F.; Vicedo-Cabrera, A.M.; de Sousa Zanotti Stagliorio Coelho, M.; Saldiva, P.H.N.; Lavigne, E.; Tawatsupa, B.; Punnasiri, K. Quantifying excess deaths related to heatwaves under climate change scenarios: A multicountry time series modelling study. PLoS Med. 2018, 15, e1002629. [CrossRef]

9. Debbage, N.; Shepherd, J.M. The urban heat island effect and city contiguity. Comput. Environ. Urban. Syst. 2015, 54, 181-194. [CrossRef]

10. Oke, T.R. City size and the urban heat island. Atmos. Environ. 1973, 7, 769-779. [CrossRef]

11. Santamouris, M.; Cartalis, C.; Synnefa, A.; Kolokotsa, D. On the impact of urban heat island and global warming on the power demand and electricity consumption of buildings-A review. Energy Build. 2015, 98, 119-124. [CrossRef]

12. Stewart, I.D.; Oke, T.R. Local climate zones for urban temperature studies. Bull. Am. Meteorol. Soc. 2012, 93, 1879-1900. [CrossRef]

13. Stewart, I.D.; Oke, T.R.; Krayenhoff, E.S. Evaluation of the 'local climate zone'scheme using temperature observations and model simulations. Int. J. Climatol. 2014, 34, 1062-1080. [CrossRef]

14. Kaloustian, N.; Bechtel, B. Local climatic zoning and urban heat island in Beirut. Procedia Eng. 2016, 169, 216-223. [CrossRef]

15. Cai, M.; Ren, C.; Xu, Y.; Lau, K.K.-L.; Wang, R. Investigating the relationship between local climate zone and land surface temperature using an improved WUDAPT methodology-A case study of Yangtze River Delta, China. Urban. Clim. 2018, 24, 485-502. [CrossRef]

16. Bechtel, B.; Alexander, P.J.; Böhner, J.; Ching, J.; Conrad, O.; Feddema, J.; Mills, G.; See, L.; Stewart, I. Mapping local climate zones for a worldwide database of the form and function of cities. ISPRS Int. J. Geo-Inf. 2015, 4, 199-219. [CrossRef]

17. Bechtel, B.; Alexander, P.J.; Beck, C.; Böhner, J.; Brousse, O.; Ching, J.; Demuzere, M.; Fonte, C.; Gál, T.; Hidalgo, J. Generating WUDAPT Level 0 data-Current status of production and evaluation. Urban. Clim. 2019, 27, 24-45. [CrossRef]

18. Ching, J.; Mills, G.; Bechtel, B.; See, L.; Feddema, J.; Wang, X.; Ren, C.; Brousse, O.; Martilli, A.; Neophytou, M. WUDAPT: An urban weather, climate, and environmental modeling infrastructure for the anthropocene. Bull. Am. Meteorol. Soc. 2018, 99, 1907-1924. [CrossRef]

19. Zhang, L.; Zhang, L.; Du, B. Deep learning for remote sensing data: A technical tutorial on the state of the art. IEEE Geosci. Remote Sens. Mag. 2016, 4, 22-40. [CrossRef]

20. Liu, S.; Shi, Q. Local climate zone mapping as remote sensing scene classification using deep learning: A case study of metropolitan China. ISPRS J. Photogramm. Remote Sens. 2020, 164, 229-242. [CrossRef]

21. Qiu, C.; Tong, X.; Schmitt, M.; Bechtel, B.; Zhu, X.X. Multilevel feature fusion-based CNN for local climate zone classification from sentinel-2 images: Benchmark results on the So2Sat LCZ42 dataset. IEEE J. Sel. Top. Appl. Earth Obs. Remote Sens. 2020, 13, 2793-2806. [CrossRef]

22. Yoo, C.; Lee, Y.; Cho, D.; Im, J.; Han, D. Improving local climate zone classification using incomplete building data and Sentinel 2 images based on convolutional neural networks. Remote Sens. 2020, 12, 3552. [CrossRef]

23. Shih, W. The impact of urban development patterns on thermal distribution in Taipei. In Proceedings of the 2017 Joint Urban Remote Sensing Event (JURSE), Dubai, United Arab Emirates, 6-8 March 2017; pp. 1-5.

24. Geletič, J.; Lehnert, M.; Dobrovolný, P. Land surface temperature differences within local climate zones, based on two central European cities. Remote Sens. 2016, 8, 788. [CrossRef]

25. Koc, C.B.; Osmond, P.; Peters, A.; Irger, M. Understanding land surface temperature differences of local climate zones based on airborne remote sensing data. IEEE J. Sel. Top. Appl. Earth Obs. Remote Sens. 2018, 11, 2724-2730.

26. Zhao, C.; Jensen, J.L.; Weng, Q.; Currit, N.; Weaver, R. Use of Local Climate Zones to investigate surface urban heat islands in Texas. GIScience Remote Sens. 2020, 57, 1083-1101. [CrossRef]

27. Richard, Y.; Emery, J.; Dudek, J.; Pergaud, J.; Chateau-Smith, C.; Zito, S.; Rega, M.; Vairet, T.; Castel, T.; Thévenin, T. How relevant are local climate zones and urban climate zones for urban climate research? Dijon (France) as a case study. Urban. Clim. 2018, 26, 258-274. [CrossRef] 
28. Mushore, T.D.; Dube, T.; Manjowe, M.; Gumindoga, W.; Chemura, A.; Rousta, I.; Odindi, J.; Mutanga, O. Remotely sensed retrieval of Local Climate Zones and their linkages to land surface temperature in Harare metropolitan city, Zimbabwe. Urban. Clim. 2019, 27, 259-271. [CrossRef]

29. Verdonck, M.-L.; Demuzere, M.; Hooyberghs, H.; Beck, C.; Cyrys, J.; Schneider, A.; Dewulf, R.; Van Coillie, F. The potential of local climate zones maps as a heat stress assessment tool, supported by simulated air temperature data. Landsc. Urban Plan. 2018, 178, 183-197. [CrossRef]

30. Yang, X.; Yao, L.; Jin, T.; Peng, L.L.; Jiang, Z.; Hu, Z.; Ye, Y. Assessing the thermal behavior of different local climate zones in the Nanjing metropolis, China. Build. Environ. 2018, 137, 171-184. [CrossRef]

31. Zhongli, L.; Hanqiu, X. A study of urban heat island intensity based on "local climate zones": A case study in Fuzhou, China. In Proceedings of the 2016 4th International Workshop on Earth Observation and Remote Sensing Applications (EORSA), Guangzhou, China, 4-6 July 2016; pp. 250-254.

32. Chen, A.; Yao, L.; Sun, R.; Chen, L. How many metrics are required to identify the effects of the landscape pattern on land surface temperature? Ecol. Indic. 2014, 45, 424-433. [CrossRef]

33. Huang, X.; Wang, Y. Investigating the effects of 3D urban morphology on the surface urban heat island effect in urban functional zones by using high-resolution remote sensing data: A case study of Wuhan, Central China. ISPRS J. Photogramm. Remote Sens. 2019, 152, 119-131. [CrossRef]

34. Peng, J.; Jia, J.; Liu, Y.; Li, H.; Wu, J. Seasonal contrast of the dominant factors for spatial distribution of land surface temperature in urban areas. Remote Sens. Environ. 2018, 215, 255-267. [CrossRef]

35. Peng, W.; Zhang, D.; Luo, Y.; Tao, S.; Xu, X. Influence of natural factors on vegetation NDVI using geographical detection in Sichuan Province. Acta Geogr. Sin. 2019, 74, 1758.

36. Wang, J.; Xu, C. Geodetector: Principle and prospective. Acta Geogr. Sin. 2017, 72, 116-134.

37. Ren, Y.; Deng, L.; Zuo, S.; Luo, Y.; Shao, G.; Wei, X.; Hua, L.; Yang, Y. Geographical modeling of spatial interaction between human activity and forest connectivity in an urban landscape of southeast China. Landsc. Ecol. 2014, 29, 1741-1758. [CrossRef]

38. Han, Z.; Zhiyuan, R. Remote sensing analysis of vegetation phenology characteristics in Shaanxi province based on Whittaker smoother method. J. Desert Res. 2015, 35, 901-906.

39. Liao, Y.; Zhang, Y.; He, L.; Wang, J.; Liu, X.; Zhang, N.; Xu, B. Temporal and spatial analysis of neural tube defects and detection of geographical factors in Shanxi Province, China. PLoS ONE 2016, 11, e0150332. [CrossRef]

40. Zhou, L.; Wu, J.; Jia, R.; Liang, N.; Zhang, F.; Ni, Y.; Liu, M. Investigation of temporal-spatial characteristics and underlying risk factors of PM2. 5 pollution in Beijing-Tianjin-Hebei Area. Res. Environ. Sci. 2016, 29, 483-493.

41. Ding, Y.; Cai, J.; Ren, Z.; Yang, Z. Spatial disparities of economic growth rate of China's National-level ETDZs and their determinants based on geographical detector analysis. Prog. Geogr. 2014, 5, 657-666.

42. Shuoben, B.; Han, J.; Changchun, C.; Hongru, Y.; Xiang, S. Application of geographical detector in human-environment relationship study of prehistoric settlements. Prog. Geogr. 2015, 34, 118-127.

43. Yokoya, N.; Ghamisi, P.; Xia, J.; Sukhanov, S.; Heremans, R.; Tankoyeu, I.; Bechtel, B.; Le Saux, B.; Moser, G.; Tuia, D. Open data for global multimodal land use classification: Outcome of the 2017 IEEE GRSS Data Fusion Contest. IEEE J. Sel. Top. Appl. Earth Obs. Remote Sens. 2018, 11, 1363-1377. [CrossRef]

44. Zhu, X.X.; Hu, J.; Qiu, C.; Shi, Y.; Kang, J.; Mou, L.; Bagheri, H.; Häberle, M.; Hua, Y.; Huang, R. So2Sat LCZ42: A benchmark dataset for global local climate zones classification. IEEE Geosci. Remote Sens. Mag. 2020, 8, 76-89. [CrossRef]

45. He, K.; Zhang, X.; Ren, S.; Sun, J. Deep residual learning for image recognition. In Proceedings of the IEEE conference on computer vision and pattern recognition, Las Vegas, NV, USA, 27-30 June 2016; pp. 770-778.

46. Woo, S.; Park, J.; Lee, J.-Y.; Kweon, I.S. Cbam: Convolutional block attention module. In Proceedings of the European Conference on Computer Vision (ECCV), Munich, Germany, 8-14 September 2014; pp. 3-19.

47. Howard, A.G.; Zhu, M.; Chen, B.; Kalenichenko, D.; Wang, W.; Weyand, T.; Andreetto, M.; Adam, H. Mobilenets: Efficient convolutional neural networks for mobile vision applications. arXiv 2017, arXiv:1704.04861.

48. Tobler, W.R. A computer movie simulating urban growth in the Detroit region. Econ. Geogr. 1970, 46, 234-240. [CrossRef]

49. Tucker, C.J.; Vanpraet, C.L.; Sharman, M.; Van Ittersum, G. Satellite remote sensing of total herbaceous biomass production in the Senegalese Sahel: 1980-1984. Remote Sens. Environ. 1985, 17, 233-249. [CrossRef]

50. Zha, Y.; Gao, J.; Ni, S. Use of normalized difference built-up index in automatically mapping urban areas from TM imagery. Int. J. Remote Sens. 2003, 24, 583-594. [CrossRef]

51. $\mathrm{Xu}, \mathrm{H}$. Modification of normalised difference water index (NDWI) to enhance open water features in remotely sensed imagery. Int. J. Remote Sens. 2006, 27, 3025-3033. [CrossRef]

52. $\mathrm{Xu}, \mathrm{H}$. A new index for delineating built-up land features in satellite imagery. Int. J. Remote Sens. 2008, 29, 4269-4276. [CrossRef]

53. Cook, M.; Schott, J.R.; Mandel, J.; Raqueno, N. Development of an operational calibration methodology for the Landsat thermal data archive and initial testing of the atmospheric compensation component of a Land Surface Temperature (LST) product from the archive. Remote Sens. 2014, 6, 11244-11266. [CrossRef]

54. Yao, R.; Wang, L.; Huang, X.; Zhang, W.; Li, J.; Niu, Z. Interannual variations insurface urban heat island intensity and associated drivers in China. J. Environ. Manag. 2018, 222, 86-94. [CrossRef] [PubMed]

55. Yu, B.; Tang, M.; Wu, Q.; Yang, C.; Deng, S.; Shi, K.; Peng, C.; Wu, J.; Chen, Z. Urban built-up area extraction from log-transformed NPP-VIIRS nighttime light composite data. IEEE Geosci. Remote Sens. Lett. 2018, 15, 1279-1283. [CrossRef] 
56. Sun, Y.; Gao, C.; Li, J.; Li, W.; Ma, R. Examining urban thermal environment dynamics and relations to biophysical composition and configuration and socio-economic factors: A case study of the Shanghai metropolitan region. Sustain. Cities Soc. 2018, 40, 284-295. [CrossRef]

57. Lloyd, C.T.; Sorichetta, A.; Tatem, A.J. High resolution global gridded data for use in population studies. Sci. Data 2017, 4, 1-17. [CrossRef] [PubMed]

58. Unger, J.; Lelovics, E.; Gál, T. Local Climate Zone mapping using GIS methods in Szeged. Hung. Geogr. Bull. 2014, 63, $29-41$. [CrossRef]

59. Tripathy, B.R.; Sajjad, H.; Elvidge, C.D.; Ting, Y.; Pandey, P.C.; Rani, M.; Kumar, P. Modeling of electric demand for sustainable energy and management in India using spatio-temporal DMSP-OLS night-time data. Environ. Manag. 2018, 61, 615-623. [CrossRef]

60. He, S.; Zhang, Y.; Gu, Z.; Su, J. Local climate zone classification with different source data in Xi'an, China. Indoor Built Environ. 2019, 28, 1190-1199. [CrossRef]

61. Quan, J. Enhanced geographic information system-based mapping of local climate zones in Beijing, China. Sci. China Technol. Sci. 2019, 62, 2243-2260. [CrossRef]

62. Yang, J.; Jin, S.; Xiao, X.; Jin, C.; Xia, J.C.; Li, X.; Wang, S. Local climate zone ventilation and urban land surface temperatures: Towards a performance-based and wind-sensitive planning proposal in megacities. Sustain. Cities Soc. 2019, 47, 101487. [CrossRef]

63. Estoque, R.C.; Murayama, Y.; Myint, S.W. Effects of landscape composition and pattern on land surface temperature: An urban heat island study in the megacities of Southeast Asia. Sci. Total Environ. 2017, 577, 349-359. [CrossRef]

64. Wang, M.; Zhang, Z.; Hu, T.; Liu, X. A practical single-channel algorithm for land surface temperature retrieval: Application to Landsat series data. J. Geophys. Res. Atmos. 2019, 124, 299-316. [CrossRef]

65. Wang, M.; Zhang, Z.; Hu, T.; Wang, G.; He, G.; Zhang, Z.; Li, H.; Wu, Z.; Liu, X. An Efficient Framework for Producing Landsat-Based Land Surface Temperature Data Using Google Earth Engine. IEEE J. Sel. Top. Appl. Earth Obs. Remote Sens. 2020, 13, 4689-4701. [CrossRef]

66. Gao, F.; Li, S.; Tan, Z.; Wu, Z.; Zhang, X.; Huang, G.; Huang, Z. Understanding the modifiable areal unit problem in dockless bike sharing usage and exploring the interactive effects of built environment factors. Int. J. Geogr. Inf. Sci. 2021, 35, 1905-1925. [CrossRef]

67. Alexander, P.J.; Mills, G. Local climate classification and Dublin's urban heat island. Atmosphere 2014, 5, 755-774. [CrossRef]

68. Leconte, F.; Bouyer, J.; Claverie, R.; Pétrissans, M. Using Local Climate Zone scheme for UHI assessment: Evaluation of the method using mobile measurements. Build. Environ. 2015, 83, 39-49. [CrossRef]

69. Wang, Y.; Zhan, Q.; Ouyang, W. Impact of urban climate landscape patterns on land surface temperature in Wuhan, China. Sustainability 2017, 9, 1700. [CrossRef]

70. Javanroodi, K.; Mahdavinejad, M.; Nik, V.M. Impacts of urban morphology on reducing cooling load and increasing ventilation potential in hot-arid climate. Appl. Energy 2018, 231, 714-746. [CrossRef]

71. Hu, D.; Meng, Q.; Zhang, L.; Zhang, Y. Spatial quantitative analysis of the potential driving factors of land surface temperature in different "Centers" of polycentric cities: A case study in Tianjin, China. Sci. Total Environ. 2020, 706, 135244. [CrossRef]

72. Chen, D.; Hu, M.; Guo, Y.; Dahlgren, R.A. Changes in river water temperature between 1980 and 2012 in Yongan watershed, eastern China: Magnitude, drivers and models. J. Hydrol. 2016, 533, 191-199. [CrossRef]

73. Sinokrot, B.A.; Stefan, H.G. Stream temperature dynamics: Measurements and modeling. Water Resour. Res. 1993, $29,2299-2312$. [CrossRef]

74. Li, J.; Xia, Z.; Wang, Y. Impact of the Three Gorges and Gezhouba reservoirs on ecohydrological conditions for sturgeon in the Yangtze River, China. J. Hydrol. Eng. 2013, 18, 1563-1570. [CrossRef]

75. Hong, T.L.Y.; Lv, H.; Meng, B.; Bi, S.; Zhou, L. Patterns of Phytoplankton Phenology and Its Response to Temperature of Water Surface in Lake Taihu based on MODIS Data. J. Geo-Inf. Sci. 2020, 22, 1935-1945.

76. Huang, J.; Wang, J.; Bo, Y.; Xu, C.; Hu, M.; Huang, D. Identification of health risks of hand, foot and mouth disease in China using thegeographical detector technique. Int. J. Environ. Res. Public Health 2014, 11, 3407-3423. [CrossRef]

77. Ren, Y.; Deng, L.; Zuo, S.; Song, X.; Liao, Y.; Xu, C.; Chen, Q.; Hua, L.; Li, Z. Quantifying the influences of various ecological factors on land surface temperature of urban forests. Environ. Pollut. 2016, 216, 519-529. [CrossRef]

78. Wu, R.; Zhang, J.; Bao, Y.; Zhang, F. Geographical detector model for influencing factors of industrial sector carbon dioxide emissions in Inner Mongolia, China. Sustainability 2016, 8, 149. [CrossRef]

79. Luo, W.; Jasiewicz, J.; Stepinski, T.; Wang, J.; Xu, C.; Cang, X. Spatial association between dissection density and environmental factors over the entire conterminous United States. Geophys. Res. Lett. 2016, 43, 692-700. [CrossRef] 